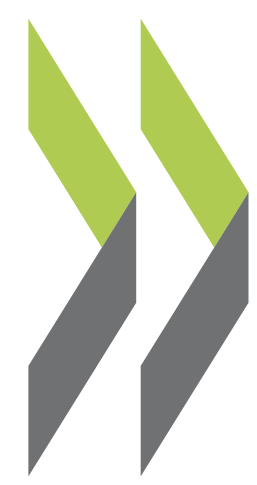

OECD Economics Department Working Papers No. 1367

Rebalancing Turkey's growth by improving resource allocation and productivity in manufacturing
Aslihan Atabek,

Dan Andrews, Rauf Gönenç 
Organisation de Coopération et de Développement Économiques

Organisation for Economic Co-operation and Development

19-Dec-2016

ECONOMICS DEPARTMENT

English - Or. English

\section{REBALANCING TURKEY'S GROWTH BY IMPROVING RESOURCE ALLOCATION AND PRODUCTIVITY IN MANUFACTURING}

ECONOMICS DEPARTMENT WORKING PAPERS No. 1367

By Aslihan Atabek, Dan Andrews and Rauf Gönenç

OECD Working Papers should not be reported as representing the official views of the OECD or of its member countries. The opinions expressed and arguments employed are those of the authors.

Authorised for publication by Robert Ford, Deputy Director, Country Studies Branch, Economics Department.

All Economics Department Working Papers are available at www.oecd.org/eco/workingpapers

JT03407302

Complete document available on OLIS in its original format

This document and any map included herein are without prejudice to the status of or sovereignty over any territory, to the delimitation of international frontiers and boundaries and to the name of any territory, city or area. 
OECD Working Papers should not be reported as representing the official views of the OECD or of its member countries. The opinions expressed and arguments employed are those of the author(s).

Working Papers describe preliminary results or research in progress by the author(s) and are published to stimulate discussion on a broad range of issues on which the OECD works.

Comments on Working Papers are welcomed, and may be sent to the Economics Department, OECD, 2 rue André-Pascal, 75775 Paris Cedex 16, France, or by e-mail to eco.contact@ oecd.org.

All Economics Department Working Papers are available at www.oecd.org/eco/workingpapers

This document and any map included herein are without prejudice to the status of or sovereignty over any territory, to the delimitation of international frontiers and boundaries and to the name of any territory, city or area.

The statistical data for Israel are supplied by and under the responsibility of the relevant Israeli authorities. The use of such data by the OECD is without prejudice to the status of the Golan Heights, East Jerusalem and Israeli settlements in the West Bank under the terms of international law.

Latvia was not an OECD member at the time of preparation of this paper. Accordingly, Latvia does not appear in the list of OECD Members and is not included in the zone aggregates.

\section{(C) OECD (2016)}

You can copy, download or print OECD content for your own use, and you can include excerpts from OECD publications, databases and multimedia products in your own documents, presentations, blogs, websites and teaching materials, provided that suitable acknowledgment of OECD as source and copyright owner is given. All requests for commercial use and translation rights should be submitted to rights@oecd.org 
ECO/WKP(2016)91

\section{ABSTRACT/RÉSUMÉ}

\section{Rebalancing Turkey's growth by improving resource allocation and productivity in manufacturing}

Turkey's manufacturing sector has expanded considerably but not efficiently and competitively enough. This paper documents the drivers of its recent growth and diversification, and the factors that have held it back. It documents its segmentation and the outsized tail of poorly performing firms, which undermines aggregate productivity growth. Low productivity eases job creation in the short term, but undermines it in the long run and holds back improvements in living standards because of competitiveness losses. A core of well-performing firms ("frontier firms") is not growing at full potential because of shortcomings in the policy framework. Intermediary ("follower") firms sustain competition and deliver jobs, but tend to fall behind in productivity. Lower productivity units ("laggards"), which employ a large share of the low-skilled majority of the working age population, survive mostly thanks to the incomplete enforcement of rules and regulations. The resulting stalemate requires a coherent strategy of "systemic upgrading" of the business environment. This would enable all firms to operate in compliance with the law and on a level-playing field, under supportive regulations, taxation and innovation incentives. All firms could then achieve stronger productivity gains and the most promising firms could grow faster. At the same time, a credible flexicurity system needs to be put in place that facilitates adjustment in the labour market while protecting those affected by structural change.

This working paper relates to the 2016 OECD Economic Survey of Turkey (www.oecd.org/eco/surveys/economic-survey-turkey.htm).

\section{JEL Classification: J2; J3; O1;O4; O5}

Keywords: Turkey, growth, productivity, structural change, taxation, labour markets, informality

$* * * * * * * * * * * * * *$

\section{Rééquilibrer la croissance turque en améliorant l'allocation des ressources et la productivité}

Le secteur manufacturier s'est considérablement développé en Turquie, mais pas de manière suffisamment efficace et compétitive. Ce document décrit les moteurs de sa croissance récente et de sa diversification, et les facteurs qui ont freiné sa performance. Il met en évidence sa segmentation et le poids excessif des entreprises peu performantes, qui nuit à sa croissance et à sa productivité globale. Le ralentissement de la productivité accélère la création d'emplois à court terme, mais mine le niveau de vie à long terme en raison de pertes de compétitivité. Un noyau d'entreprises très performantes («entreprises frontières») ne se développe pas à plein potentiel, en raison de lacunes dans le cadre fourni par les politiques. Un groupe d'entreprises intermédiaires («entreprises suiveurs») soutiennent la concurrence et offrent des emplois, mais leur productivité ne croit pas vite. Des unités encore inférieures en productivité (les «entreprises retardataires») emploient une proportion importante de la majorité peu qualifiée de la population en âge de travailler, et survivent grâce à l'application incomplète des lois et des règlementations. Les blocages qui en résultent appellent une stratégie cohérente de «mise à niveau systémique» de l'environnement des affaires. Cela permettrait à toutes les entreprises d'opérer en conformité avec la loi et en une concurrence équitable, dans un cadre favorable de règles, de taxes et d'incitations à l'innovation. Toutes les entreprises pourraient alors réaliser des gains de productivité plus importants et les entreprises les plus prometteuses pourraient croître plus vite. En même temps, un système de flexicurité crédible doit être mis en place, pour faciliter les ajustements sur le marché du travail tout en protégeant les personnes touchées par les changements structurels.

Ce Document de travail se rapporte à l'Étude économique de l'OCDE de la Turquie 2016 (www.oecd.org/fr/eco/etudes/etude-economique-turquie.htm).

JEL Classification: J2; J3; O1;O4; O5

Mots clefs : Turquie, croissance, productivité, changement structurel, marché de travail, informalité 


\section{TABLE OF CONTENTS}

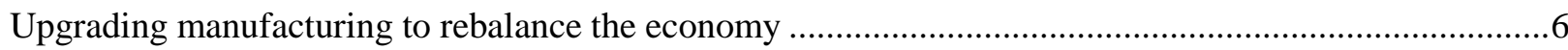

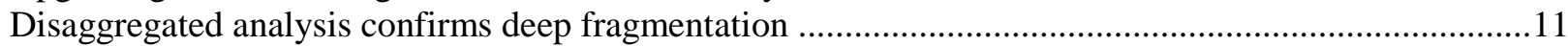

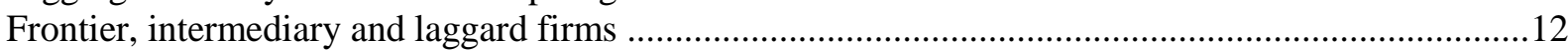

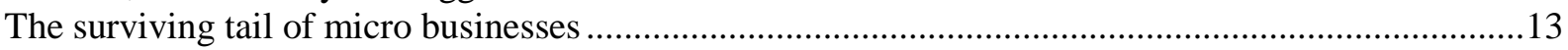

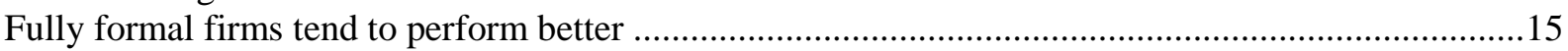

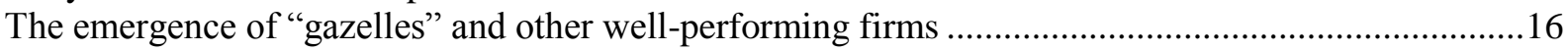

The fully formal sector is not developing at full potential....................................................................17

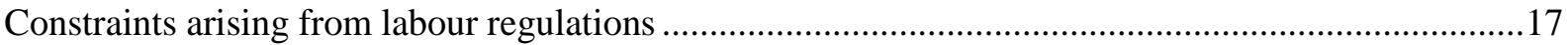

Very large firms and FDI are undersized in international comparison ...........................................19

Sophisticated start-ups are penalised by shortcomings in the business environment.............................20

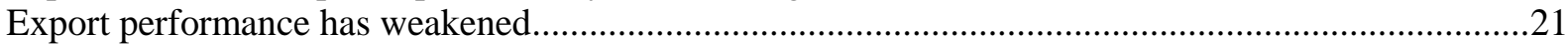

Labour allocation is particularly poor in labour-intensive industries...................................................22

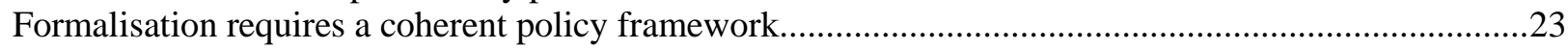

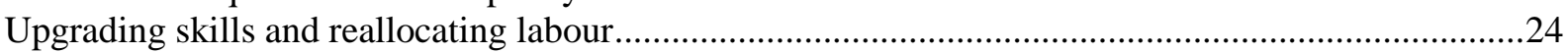

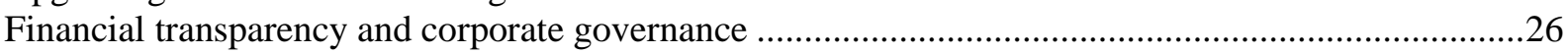

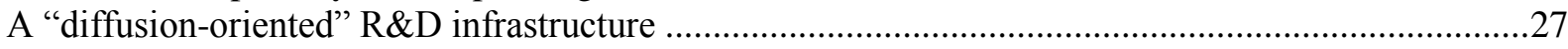

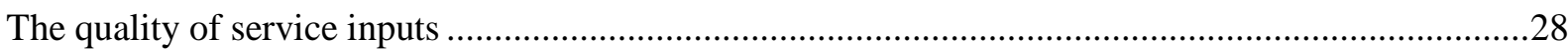

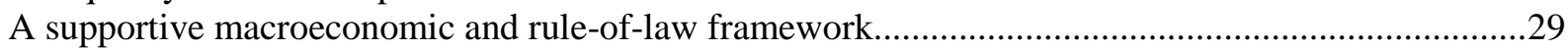

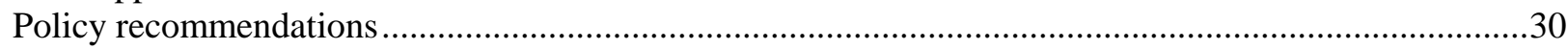

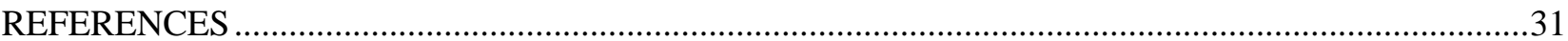

APPENDIX 1 THE EFFICIENCY OF LABOUR ALLOCATION IN LABOUR-INTENSIVE AND

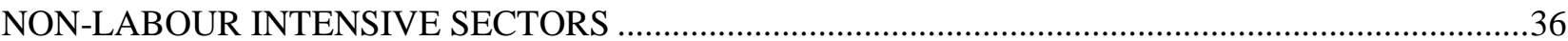

\section{Tables}

1. Manufacturing led employment growth in emerging regions : estimation results .................................

2. Industry-relevant measures of the 2016 Action Plan .........................................................................24

A.1. Allocative efficiency in manufacturing sectors...............................................................................38

A.2. Simulated labour productivity gains from reducing the allocative efficiency gap between labour

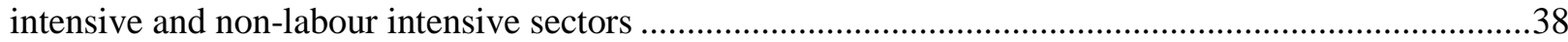

\section{Figures}

Figure 1. Broad-based industrialisation has promoted social inclusion..................................................

Figure 2. Job creation in manufacturing led broad-based employment growth in catching-up regions ......8

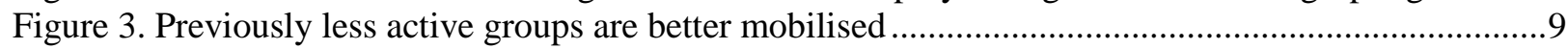

Figure 4. Turkish manufacturing underperforms international peers ....................................................10

Figure 5. Manufacturing employment according to firm size and technology level ...............................12

Figure 6. Productivity divergence within the manufacturing sector ........................................................13

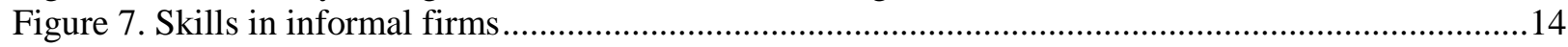

Figure 8. Allocation of wage earners according to their education level...............................................15

Figure 9. Institutionalised firms achieve higher productivity growth but create fewer jobs......................15

Figure 10. Productivity divergence within fully formal manufacturing ..................................................16 
Figure 11. Gazelle firms in institutionalised versus total manufacturing ..............................................17

Figure 12. Room for progress in corporate governance ......................................................................19

Figure 13. Room for more growth by institutionalised firms ...............................................................20

Figure 14. Investment obstacles reported by fully formal firms ......................................................21

Figure 15. Export intensity has weakened overall, but improved in dynamic areas .................................22

Figure 16. Resource allocation efficiency in total and fully formal manufacturing ................................23

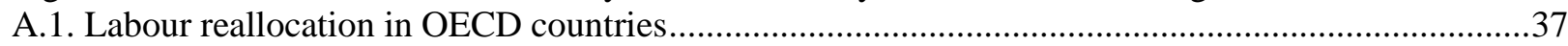

\section{Boxes}

Box 1. Manufacturing led broader employment growth in many emerging regions ..................................

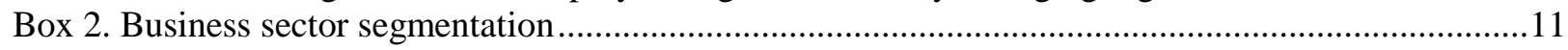




\title{
REBALANCING TURKEY'S GROWTH BY IMPROVING RESOURCE ALLOCATION AND PRODUCTIVITY IN MANUFACTURING
}

\author{
Aslihan Atabek, Dan Andrews and Rauf Gönenç ${ }^{1}$
}

\section{Upgrading manufacturing to rebalance the economy}

Rebalancing Turkey's growth path in order to make it externally sustainable requires a durable improvement in international competitiveness. Demand must be rebalanced between domestic and external sources, and supply between domestic and export-oriented activities. A more competitive manufacturing sector, with a heavier weight in the economy and higher net exports can deliver such rebalancing. Many other activities - including agriculture, mining, construction, tourism - generate tradeable value added but manufacturing is particularly important. Even in regions with poor natural resources and low local demand levels, manufacturing can generate higher-earning jobs and contribute to broad-based growth and social inclusion.

Manufacturing sector competitiveness can be enhanced via reductions in the cost of capital and labour. There is indeed room for such reductions. Real interest rates for premium borrowers declined sharply in Turkey since the mid-2000s (OECD, 2010a), but are still above comparable countries. Employment costs for low-skilled workers are high, especially after the $30 \%$ increase in the official minimum wage in January 2016. Social contribution cuts can serve to reduce those costs but entail a fiscal burden. Against this background, improving productivity via more efficient production processes, greater product differentiation and higher value added is the most reliable and sustainable avenue for durable competitiveness gains.

Faster productivity growth first and foremost requires a significant upgrading in the quality of Turkey's human capital, as emphasized in the 2006 OECD Economic Survey of Turkey (OECD, 2006a). But productivity gains can also be achieved in the shorter term, with existing resources. Wide gaps in the productivity level and growth rates across different types of firms point to large potential productivity gains "within" and "between" firms (i.e. through efficiency gains in existing firms, and employment shifts from lower to higher productivity firms). Improving the diffusion of productivity-enhancing know-how, techniques and management practices can deliver such gains (Andrews et al., 2015).

The development of manufacturing has strengthened social inclusion but has hit a glass ceiling

Value added in Turkey's manufacturing sector has expanded by around $70 \%$ and employment by nearly 30\% between 2003 and 2013. The development of export-oriented manufacturing, not only in the traditional industrial strongholds of the West, which have expanded further, but also across the poorer regions of inland Anatolia, played a major role. This trend was documented in the 2014 OECD Economic Survey of Turkey (OECD, 2014a) and has persisted since (Figure 1 and Box 1).

Manufacturing jobs grew in all regions, albeit unevenly. Job creation was also dynamic in construction and services. Overall, and in particular in catch-up low-income regions, job creation in manufacturing appears to have provided a significant impulse to employment growth in other sectors (Box 1).

1. All authors worked in the Economics department at the time of the preparation of this paper, Mrs. Atabek was on a secondment from the CB of the Republic of Turkey. The paper benefitted from additional research by OECD Turkey Desk colleague Koray Kalafatcilar. The authors would like to thank Alvaro Pereira, Robert Ford, Vincent Koen, Volker Ziemann (all from the Economics department) and Chiara Criscuolo (Directorate for Science, Technology and Innovation) for valuable discussions and comments on earlier drafts. Special thanks are due to Economics department colleagues Béatrice Guérard for statistical assistance and to Mercedes Burgos and Sisse Nielsen for technical preparation. 
Figure 1. - Broad-based industrialisation has promoted social inclusion
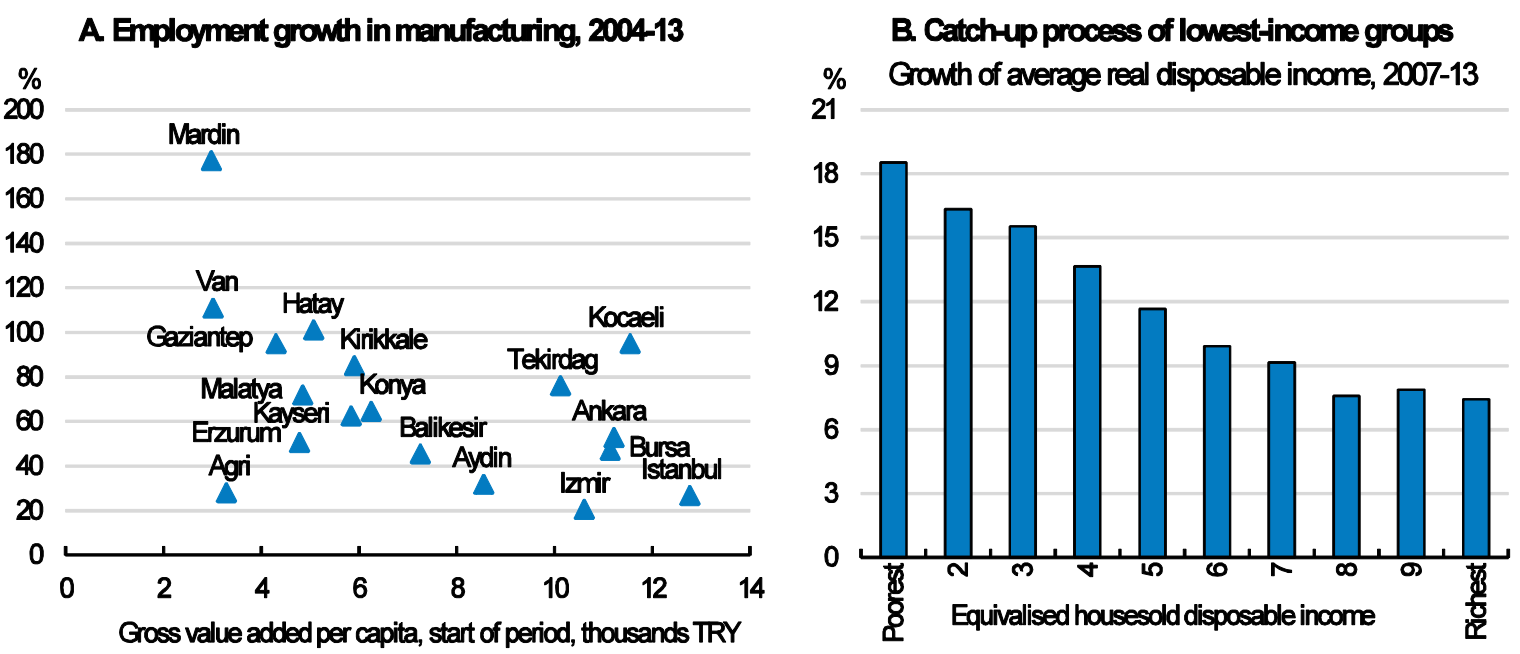

Source: Turkish Statistical Institute.

As a result of these developments, a rising share of the low-skilled majority of the population has found employment in higher-quality occupations. Men and women with less than secondary education, who represent $65 \%$ of the working age population, have been traditionally employed at the periphery of the formal labour force. Low-educated women remained inactive in urban areas, or worked as unpaid family members in agriculture. Low-educated men were mostly self-employed in low-income jobs, or were hired by small informal businesses. Workers above age 45 had a low employment rate. All these groups have started to participate more actively and to take up wage-earning jobs in formal businesses (Figure 3). This helped reduce the rate of extreme poverty (Azevedo and Atamanov, 2014), which, according to official figures, declined from $13.3 \%$ in 2006 to $1.6 \%$ in 2014. The contribution of job creation to keeping income inequality in check contrasts with experience in other countries, where social transfers played a more important role (Taşkın, 2014; Şeker and Dayığlu, 2015).

\section{Box 1. Manufacturing led broader employment growth in many emerging regions}

The profile and composition of employment in Turkey's 26 NUTS 2 regions suggests that growth and job creation in manufacturing back broader-based employment in other non-farm activities (Figure 2). This is possibly related to export-oriented activities' generating an initial increase in local enterprise and household incomes, and generating induced demand for local services and construction.

The link between job creation in manufacturing and other non-farm activities (excluding construction) was tested econometrically across Turkey's 26 NUTS-2 level regions between 2006 and 2013 (the period for which data is available) with Arellano-Bond dynamic panel estimation and fixed effect methods. The dependent variable is employment in services and other industry, and explanatory variables include manufacturing employment, both in per cent change. Both models include time dummies and variables that control for aggregate activity and regional circumstances. The data are from Turkstat's AIS database.

Table 1. Manufacturing led employment growth in emerging regions : estimation results

\begin{tabular}{l|c|c|c|c|}
\hline & Arellano-Bond & p-values & Fixed Effect & p-values \\
\hline dependent variable (t-1) & -0.316 & 0.000 & - & - \\
manufacturing & 0.339 & 0.003 & 0.260 & 0.002 \\
Manufacturing (t-1) & 0.244 & 0.000 & 0.201 & 0.032 \\
\hline
\end{tabular}

Source: OECD calculations based on data from Turkish Statistical Institute. 
Figure 2. Job creation in manufacturing led broad-based employment growth in catching-up regions
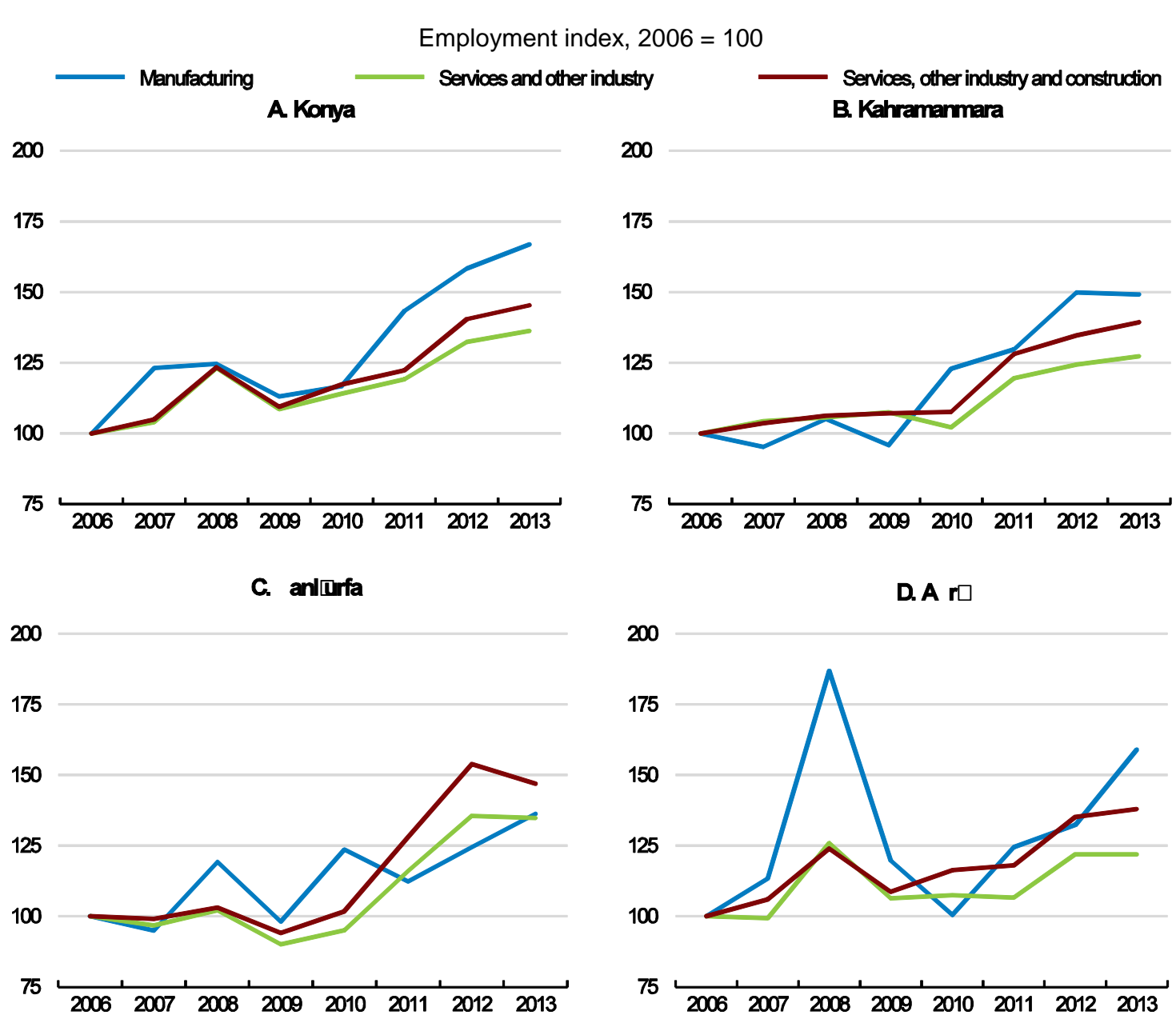

Source: Turkish Statistical Institute.

The results suggest that a $10 \%$ increase in manufacturing employment is associated with a $3.4 \%$ contemporaneous and $4.4 \%$ long-term increase (after taking into account the lagged dependent variable) in the "services and other industry" employment. The fixed effect model, similarly, suggests that a $10 \%$ increase in manufacturing employment is associated with a $2.6 \%$ contemporaneous increase, and a total increase of $4.6 \%$ in the other sectors. In level terms, the first model implies that for each job created in manufacturing, 0.77 jobs are created right away in the other sectors and 1.01 jobs over time. The corresponding gains in the second model are 0.59 and 1.05 respectively.

However, compared with other catching-up OECD economies, Turkish manufacturing has suffered from slower productivity growth, is less competitive, fares less well in international markets, and accounts for a smaller share of national output and employment (Figure 4, Panels A to D). Significant real exchange rate depreciation after the global financial crisis delivered competitiveness gains, but these did not suffice to restore the position of manufacturing against comparable countries. Exports have been gradually diversified from agricultural products and textiles-and-clothing to other sectors, such as road vehicles and electrical machinery, but the share of high-technology products remained very low (Figure 4, Panels E and F). 
Figure 3. - Previously less active groups are better mobilised

Per cent, 2014

\section{A. Employment rates of the low educated ${ }^{1}$}

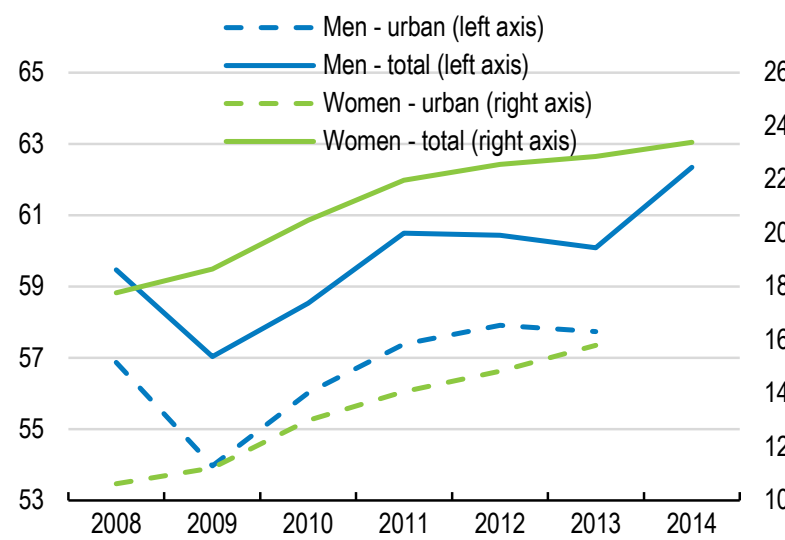

C. The majority of low-educated workers are informally employed ${ }^{12}$

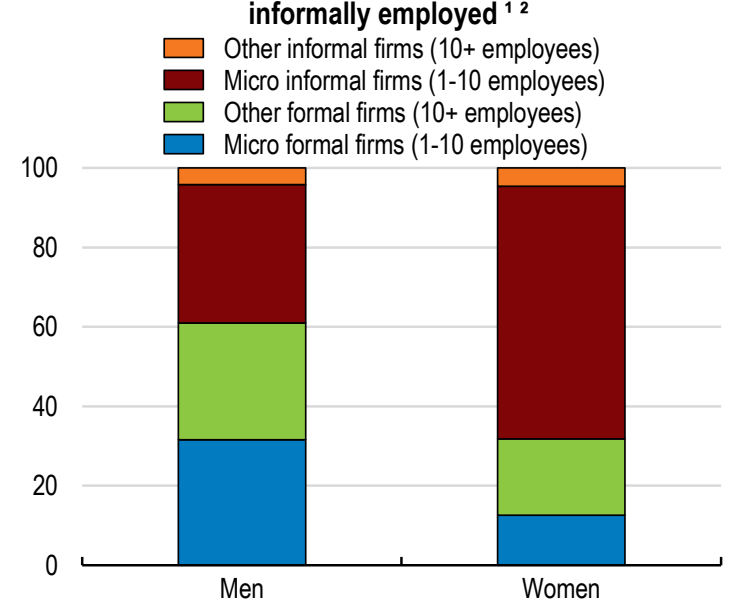

1. Persons with less than secondary education.

2. Including the self-employed.

Source: Turkish Statistical Institute.
B. Employment rates of senior workers (aged 4564 year-old)

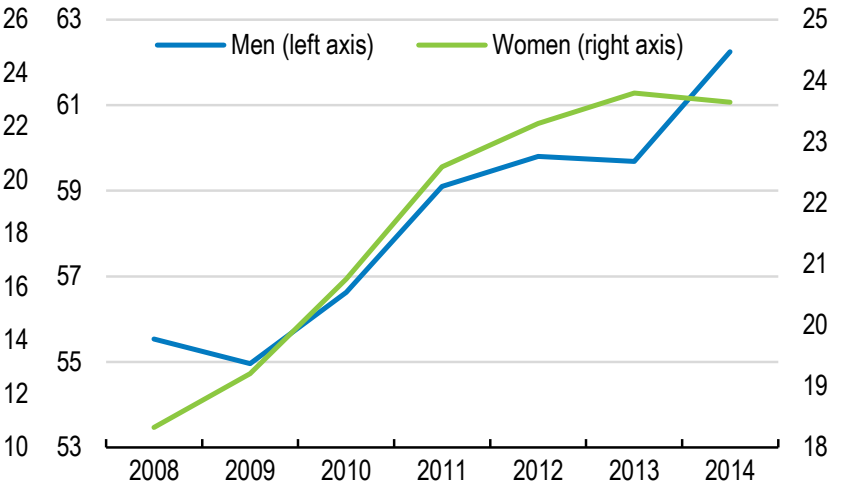

D. The majority of low-educated wage earners are formally employed ${ }^{1}$

$\square$ Other informal firms (10+ employees)

Micro informal firms (1-10 employees)

$\square$ Other formal firms (10+ employees)

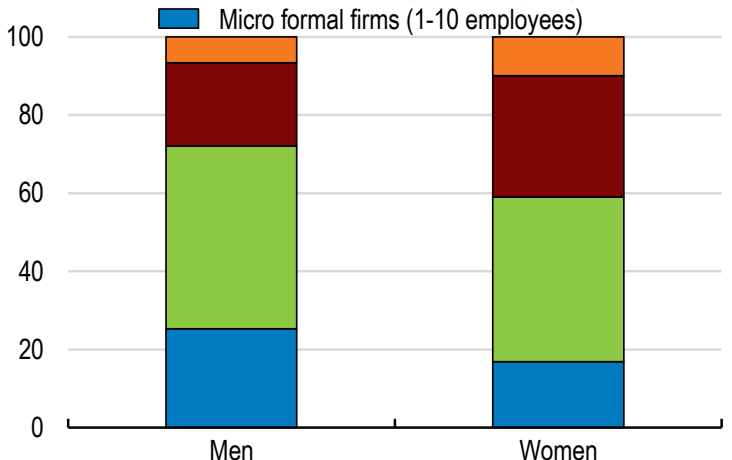


Figure 4. - Turkish manufacturing underperforms international peers

A. Productivity

Value added per worker (USD PPP, 2010 prices)

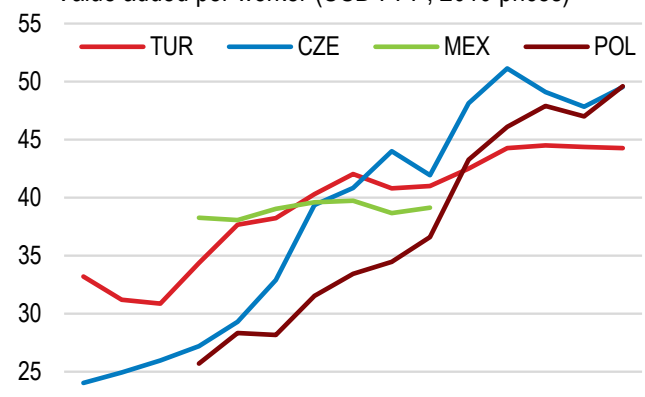

20

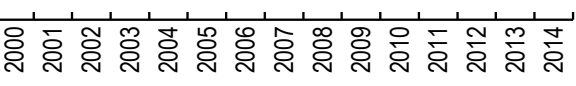

C.Share of manufacturing value added in total value added

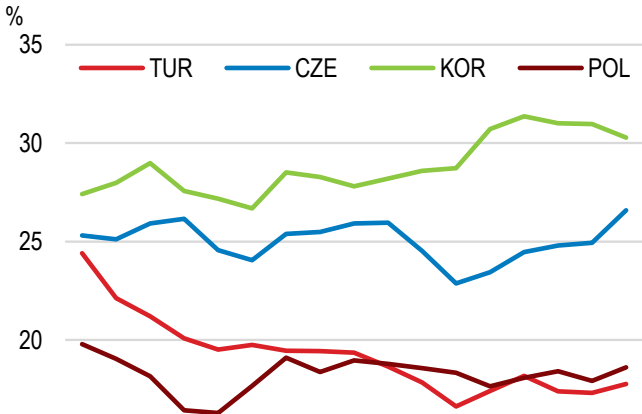

15

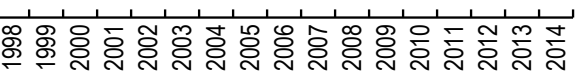

E. Sectoral composition of exports

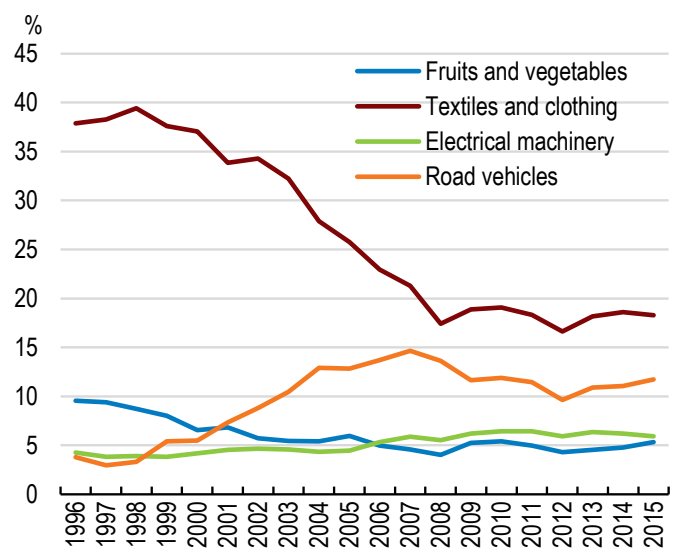

B. Shares in world exports

Index $2000=100$

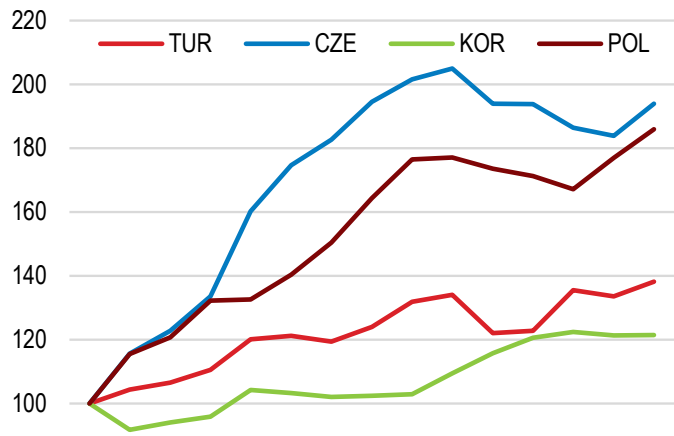

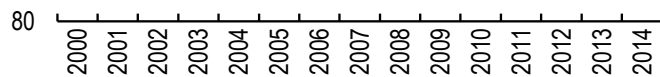

D. Share of manufacturing employment in total employment

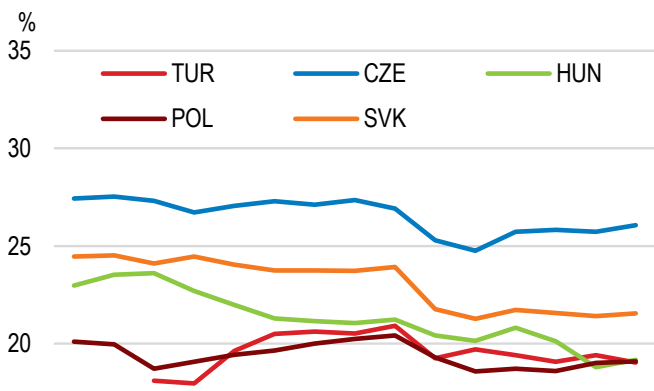

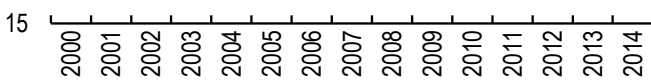

F. Technological level of exports High technology exports in \% of manufactured exports, 2014

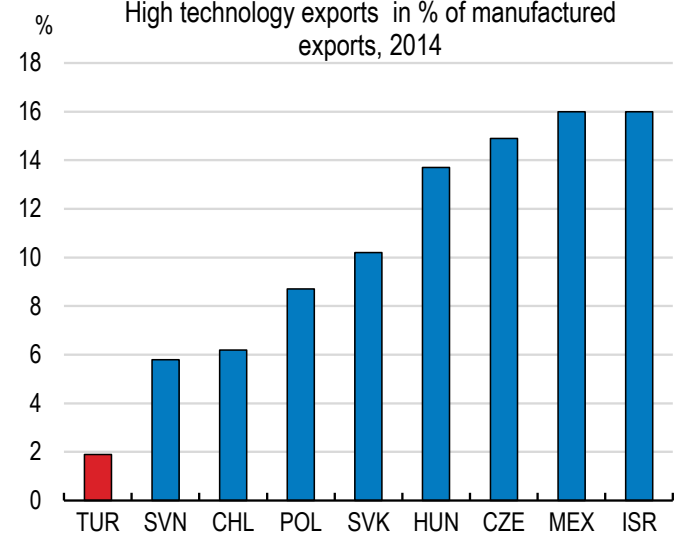

Source: OECD National accounts database; Turkish Statistical Institute; World Bank, World Development Indicators database. 
ECO/WKP(2016)91

\section{Disaggregated analysis confirms deep fragmentation}

The previous OECD Economic Survey highlighted several facets of the segmentation of the business sector (Box 2). Recent cross-country OECD work has shown how economy-wide productivity in each country reflects the more or less efficient diffusion of productivity-enhancing know-how, techniques and practices: leading national firms need to come close to global standards, and follower firms need to come close to national leaders (Andrews et al., 2015). Many factors may slow down, break up or accelerate this process. This chapter seeks to establish how well this diffusion process operates in Turkish manufacturing.

The chapter documents the distribution of firms according to their performance, with a view to assess the width of the gaps and the degree of divergence. Even though microeconomic data is incomplete, as discussed below, two microeconomic data sets provide a wealth of information:

- The national statistical office database on industry (AIS-Turkstat) is a quasi-census which in principle covers all firms, except the totally informal ones (which is a marginal group). Enterprises employing less than 20 employees are monitored through a sample. In 2013, the database covered $85 \%$ of the total manufacturing employment captured in the household labour force survey.

- The corporate balance sheets database of the central bank (CBRT) includes the enterprises that are sufficiently formalised (and financially transparent) to have regular credit relations with banks. The database thus embraces the more institutionalised part of manufacturing, which henceforth is referred to as the "fully formal sector"). As of 2013, the firms covered in this database employed $25 \%$ of the total manufacturing employment captured in the household labour force survey.

In principle, the Turkstat database covers all the firms featuring in the CBRT database. Yet, as common identification numbers are missing, and coverage is not perfect, precise overlaps cannot be identified, precluding the creation of two mutually exclusive "fully formal" versus "less formal" data sets. The chapter ponders the differences in performance between the "fully formal" and the "total" manufacturing sectors.

\section{Box 2. Business sector segmentation}

The 2014 OECD Economic Survey of Turkey distinguished five types of firms which have fared differently since the early 2000s: i) micro informal businesses (type 1); ii) semi-formal SMEs (type 2); iii) large family enterprises (type 3 ); iv) firms listed on the stock market, including FDI corporations (type 4); and v) human capital-intensive start-ups (type 5).

Type 1 (micro) and type 2 (SME) enterprises have grown faster since the 2000-01 crisis, including in the less advanced regions. However, these firms have expanded to a significant extent by circumventing Turkey's regulatory framework. In particular, labour regulations and the tax system, which had been designed for higher productivity type 3 and type 4 firms, proved ill-adapted. Most micro firms and SMEs do not operate as financially transparent and fully lawabiding enterprises. As a result, the most dynamic and job-creating part of the industry has had to rely on the "tolerance" of policymakers. In contrast, type 3, 4 and 5 firms have remained subject to costly burdens that policymakers have tried to offset with a complex set of incentives.

This has nurtured a business environment excessively exposed to the discretion of public officials in charge of enforcing regulations. Such an environment is not supportive of productivity growth: it amounts to subsidising less productive firms, while sending mixed signals to the more productive ones. It hinders within-enterprise productivity growth (as successful type 1 and type 2 firms may be deterred from growing in size) as well as between enterprise productivity gains (as type 3, 4 and 5 firms may refrain from absorbing a higher share of the labour force). FDI is undermined, as reflected in Turkey's weak FDI stock. 
Firm-level productivity can only be quantified through proxies. Firm output is measured via real (sectoral price deflated) sales of goods in the CBRT database, and adequate value added data is not available for all enterprise size groups in the Turkstat database. Faced with similar data limitations in other countries, recent international research, including at the OECD, generally opted for the use of "sales per worker" data as a proxy for labour productivity. Tests suggested that the analyses produced on the basis of this proxy are broadly congruent with those drawing on more accurate value-added based productivity indicators (Bartelsman et al., 2014; Andrews and Cingano, 2015). The latter type of data is however only available for fewer countries and for much smaller populations of firms. The analysis in this chapter uses real sales data to measure output per worker, with as much as possible a focus on growth rates rather than levels, so as to control for the fact that capital intensity and vertical integration differ across firms (Box 1.2).

\section{Frontier, intermediary and laggard firms}

The broader Turkstat database includes nearly 300000 manufacturing firms. The large majority (78\%) are micro units employing less than nine workers, 18\% small enterprises with 10 to 49 workers, $3.5 \%$ medium-size firms employing 50 to 249 employees, and less than $1 \%$ large firms with more than 250 workers. The bulk of these firms are based in developed Western regions (75\%), but $12 \%$ operate in the socalled Anatolian Tiger areas (Aydın-Denizli, Konya-Karaman, Hatay-Kahramanmaraş, Kayseri and Gaziantep). Most are in low-technology activities (64\%) such as textile and clothing, but a growing 35\% are in medium-technology areas, notably car and consumer durables production. Only $1 \%$ are in hightechnology areas. Figure 5 shows the recent evolution of the structure of employment across size groups, regions and sectors.

Figure 5. - Manufacturing employment according to firm size and technology level
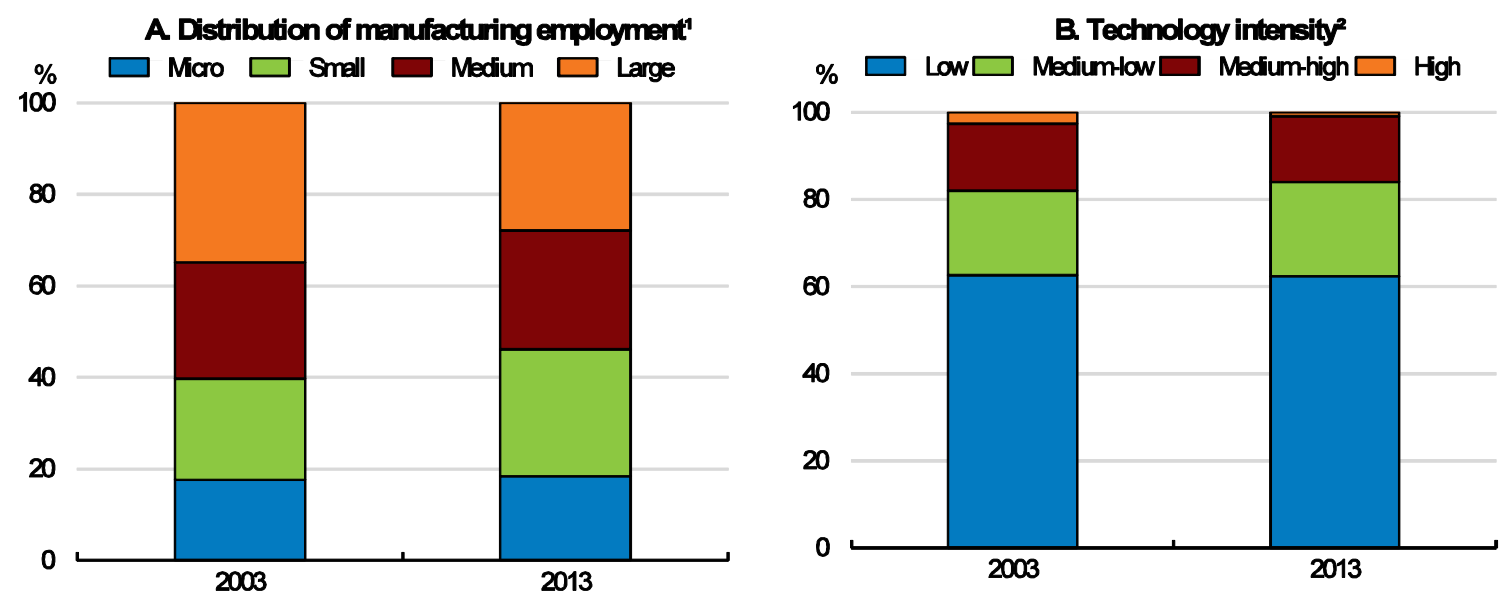

1. Micro firms employ less than 9 workers; small firms between 10-49 workers; medium firms 50-249 workers; large firms more than 250 workers.

2. Low technology: food, beverage and tobacco, textiles and clothing, wood, pulp, paper product, printing and publishing, other manufacturing. Medium-low technology: coke, refined petroleum products and nuclear fuel, rubber and plastic, non-metallic mineral products, shipbuilding, basic metals, fabricated metal products. Medium-high technology: chemicals, excluding pharmaceuticals, electrical machinery, motor vehicles, other transport equipment, non-electrical machinery. High technology: aerospace, pharmaceuticals, computers, office machinery, electronics-communications, scientific instruments.

Source: Turkish Statistical Institute.

Micro and small firms account for a large proportion of the total number of manufacturing firms in many OECD countries, but the productivity gaps between size groups is particularly large in Turkey, as 
documented in the OECD Entrepreneurship at a Glance (OECD, 2015a). The information available in the Turkstat database confirms the high degree of heterogeneity across firms, with respect to both output per worker and productivity growth. These gaps persisted through 2003-13, even if the convergence reported between micro and small firms reduced them at the lower side of the spectrum (Figure 6 Panel A).

Figure 6. - Productivity divergence within the manufacturing sector

Sales per worker, thousand TRY, 2003 prices
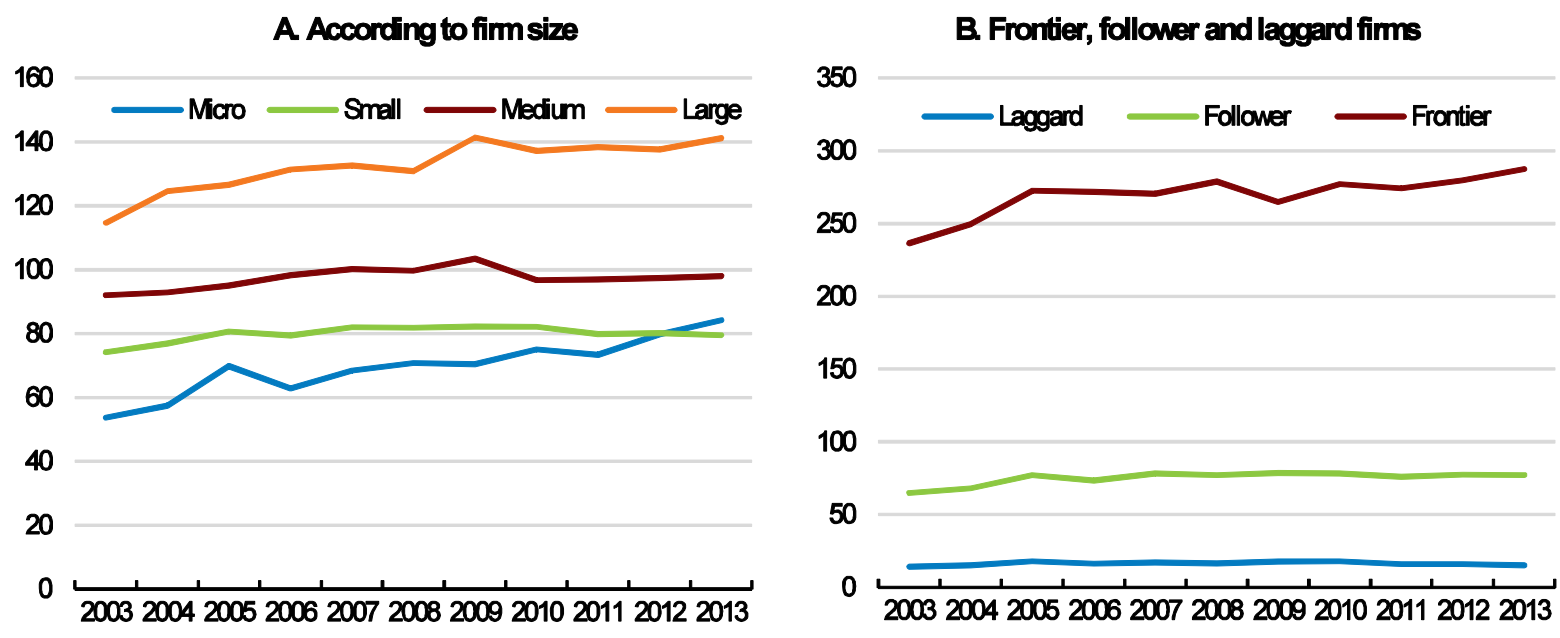

Source: Turkish Statistical Institute.

There are additional performance differences unrelated to size. The recent international literature distinguishes between the top $10 \%$ firms in sales per worker ("national frontier firms"), the bottom $20 \%$ ("laggards") and the remaining seven deciles ("intermediary" or "follower" firms). Using this typology for Turkey, sales per worker by frontier firms were four times higher in 2013 than for intermediary firms, and 10 times higher than for laggard firms. The laggards' low sales per worker and their disappointing productivity growth between 2003 and 2013 held back the aggregate performance of the economy (Figure 6, Panel B). Productivity growth between 2003 and 2013 was higher for frontier firms than for followers, and higher for the latter than for laggards. This has further widened divergences.

\section{The surviving tail of micro businesses}

International research points to two key factors explaining divergent performance between firms, irrespective of size, sector, region or factor intensity: i) managerial quality, and ii) the human capital of employees (Bloom and Van Rennen, 2012; Pellegrino and Zingales, 2014). These drive firms' capacity to converge with best business practices and technologies and therefore shape the pace of productivity diffusion in the economy (OECD, 2015f). In Turkish manufacturing, there are important managerial quality gaps across firms, which are being surveyed in the ongoing World Management Survey (results to be published in Carpio and Taşkın, 2016). The education level of workers, measured by average school years, also varies a lot.

A "tail" of micro-size businesses run by low-skilled entrepreneurs, which informally employ a majority of low-skilled workers, cumulates handicaps in both areas. These firms are covered through sampling in the Turkstat database, so information on their performance is more limited. However, other Turkstat surveys help pin down some of their characteristics. They display lower sales per worker but bear fewer legal and regulatory costs than larger firms. Many would struggle to survive in a level-playing business environment (Figure 7). 
The owners of these firms have weak human capital. They correspond to what was identified in recent cross-country research (not covering Turkey) as "informal entrepreneurs who are typically uneducated and unproductive, run small businesses producing low-quality products, and add little value" (La Porta and Shleifer, 2014). In 2013, one third of owners of all non-farm businesses in Turkey had only primary education, and an additional 15\% only lower secondary education (Turkstat, 2015). This affects the quality of management practices, including cost accounting, financial record keeping, inventory management etc., as well as firms' access to internet-based information and business platforms, and their interaction with international counterparts. Cross-country studies find that micro firms differ very much along those dimensions, and that this significantly influences their productivity and profitability (McKenzie and Woodruff, 2015).

Available information confirms that there is a deep quality split within the micro sector in Turkey. There are micro firms legally employing highly educated workers, but many others informally employing a majority of low-educated workers. The information in the Turkstat database unfortunately does not permit to distinguish the two groups for detailed analysis. However, Figure 7, which encompasses the entire business sector, shows that average school years of employees in micro firms fall significantly behind other size groups. It also reveals that, despite the fall of the share of informal wage earners to $20 \%$ in 2013 in the economy as a whole, their share in micro firms is still above $50 \%$. This suggests that the majority of micro firms have poor human capital and a low degree of institutionalisation. A large share of the population of "laggard" firms with low productivity growth can be expected to be formed of such firms.

Figure 7. - Skills in informal firms

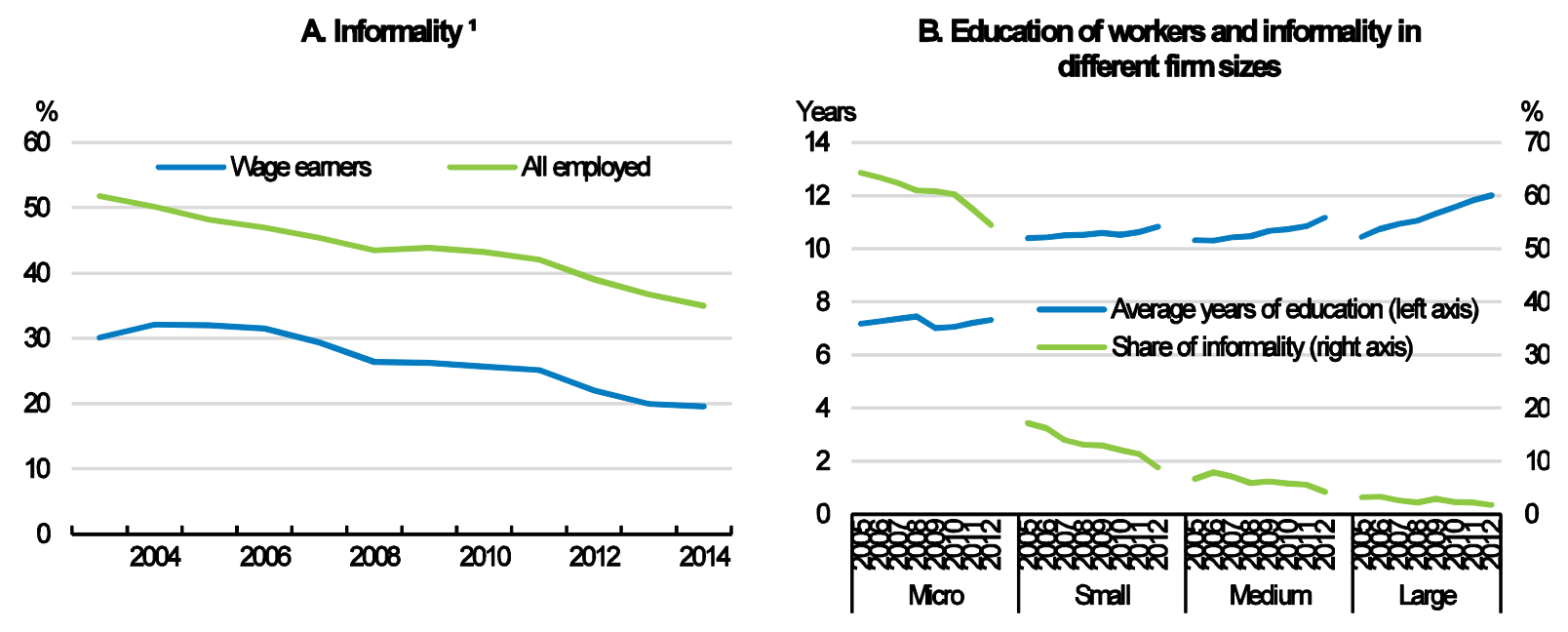

Note: Share of workers not registered with social security institutions as a proportion of all workers.

Source: Turkish Statistical Institute.

Figure 8 confirms that both men's and women's employment places vary starkly according to their education level (Figure 8, Panel B). Practically all well-educated are formally employed, many of them in high-quality micro businesses. In contrast, a large part of the low-educated, notably among women, are employed in low-quality informal micro businesses. This asymmetric distribution of human capital perpetuates the segmentation of firms. 
Figure 8. - Allocation of wage earners according to their education level 2014, thousand workers
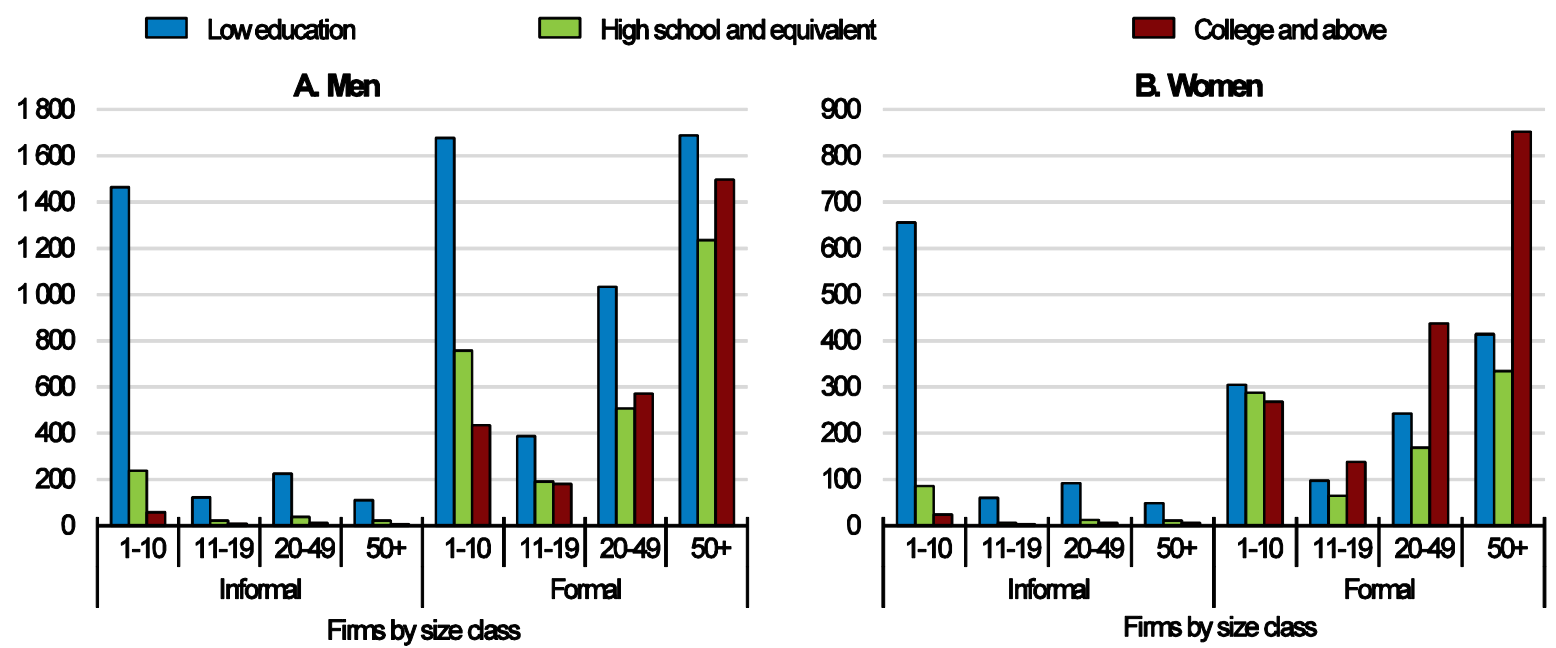

Source: Turkish Statistical Institute.

\section{Fully formal firms tend to perform better}

Sales per worker levels and productivity growth rates of the firms included in the CBRT database are significantly higher than in the broader population of firms. As a result, the productivity gap between the more and the less formalised parts of the manufacturing sector has widened over the past decade (Figure 9).

Figure 9. -Fully formal firms achieve higher productivity growth but create fewer jobs
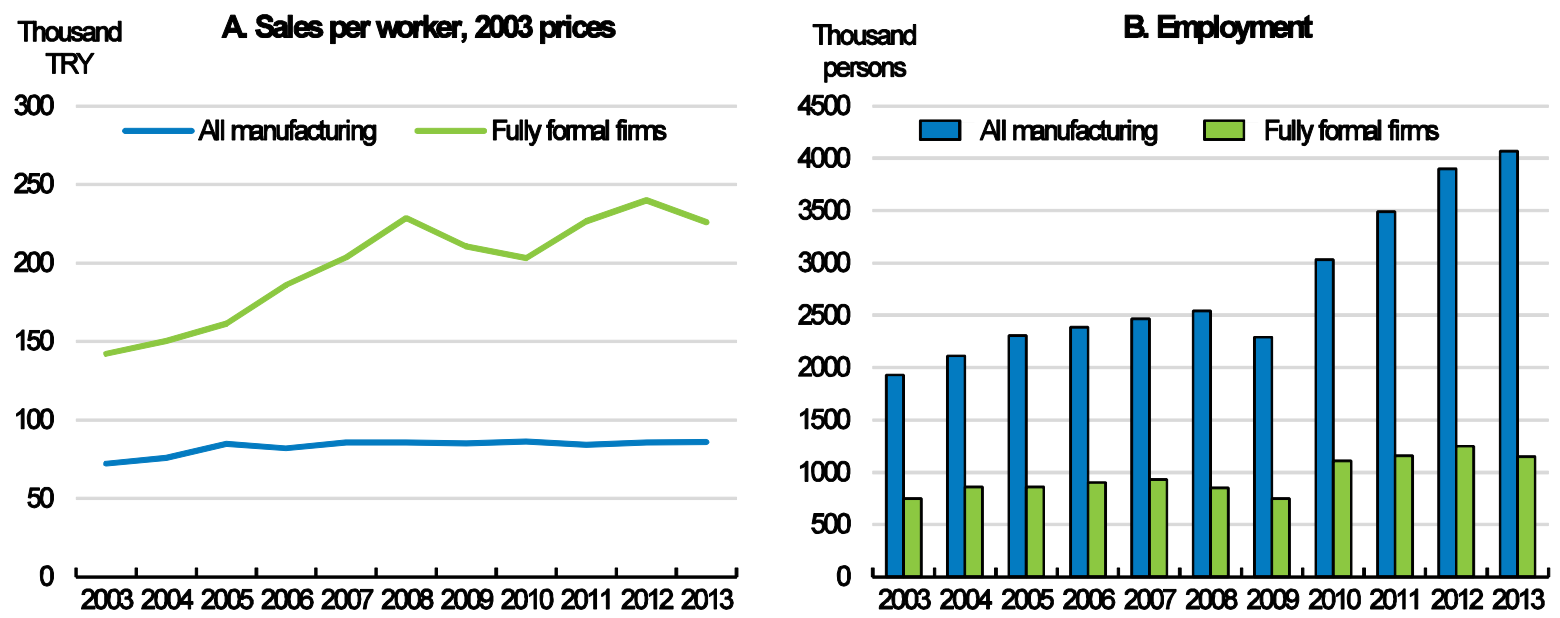

Note: All manufacturing refers to firms in the Turkstat database; fully formal firms refer to firms in the CBRT database.

Source: Turkish Statistical Institute; Central Bank of the Republic of Turkey.

Fully formal firms are larger in size and operate more frequently in medium-technology activities than less formal firms. Labour-intensive activity in these enterprises accounts for half of their total employment (a share similar to the proportion of labour-intensive activity in total manufacturing) but is carried out by 
more professionally managed and more capital-intensive firms. Overall, the fully formal enterprises in the CBRT database employ only one quarter of the workforce of the broader manufacturing population covered in the Turkstat database, but produce $60 \%$ of its total output. Average sales per worker in fully formal firms are three times higher than in total manufacturing and their productivity is growing more rapidly (Figure 9, Panel B).

One key difference between the fully formal and the broader population of firms is that the former's sales per worker levels and productivity growth rates are much more homogenous across firm sizes. However, when sorted into frontier, follower and laggard firms, fully formal firms' performance also diverges markedly, as in broader manufacturing (Figure 10). This suggests that productivity diffusion does not function well in the fully formal sector either. As a group, frontier firms achieve higher productivity gains than followers, which in turn outperform laggards in this respect. This deepens further the performance gaps inside the fully formal sector (Figure 10).

Figure 10. - Productivity divergence within fully formal manufacturing Sales per worker, thousand TRY, 2003 prices

A. According to firmsize

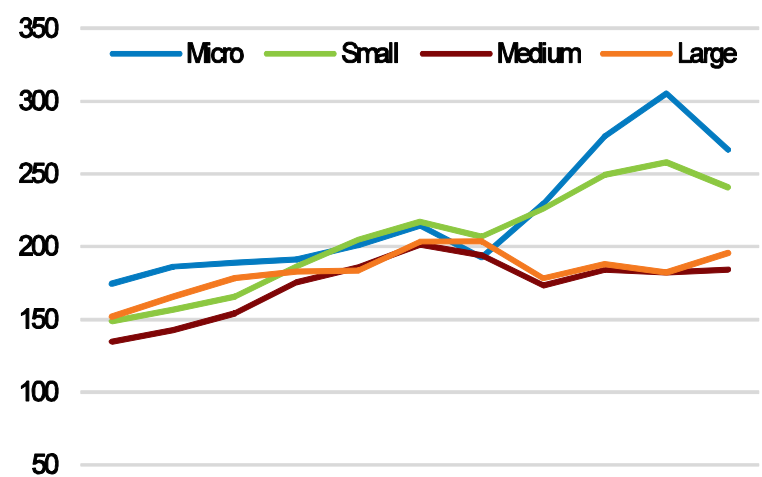

$0 \quad \frac{1}{20032004200520062007200820092010} 201120122013$
B. Frontier, follower and laggard firms

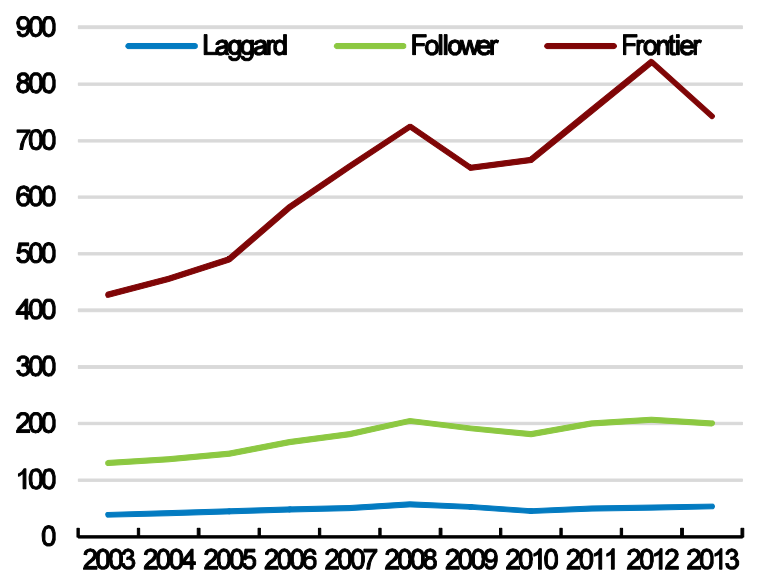

Source: Central Bank of the Republic of Turkey.

Frontier firms in the fully formal sector are very diverse: many operate in labour-intensive activities and half of them are in allegedly "low-technology" sectors, and their size varies. The presence of highperformance small fully formal enterprises would deserve further scrutiny. Information on the owners, skills, workers and other characteristics of these high performers is not available. However, the international literature documents their presence in other OECD countries too, and shows that they are generally highly human capital intensive, are internationalised, and are able to adjust to the global frontier in information technologies. These capabilities help them surmount the productivity handicaps of small size (Baya-Moriones and Lera-Lopez, 2007; Goode and Stevens, 2000). Some small-sample reviews of such Turkish firms suggest that they share the same performance drivers as their international counterparts (TOBB-TEPAV, 2015; Webrazzi, 2015).

\section{The emergence of "gazelles" and other well-performing firms}

The so-called "gazelle" firms are particularly powerful conducts of productivity diffusion in the economy (Nightingale and Coad, 2013; Altomonte, 2011). Defined as the top third of all firms in terms of both productivity growth and job creation in any single year, they have been identified separately both in the Turkstat and CBRT populations (Figure 11). Like in other OECD economies, they contribute disproportionately to compositional shifts of employment towards higher productivity areas and therefore 
to total productivity growth. The comparison of the performance of gazelles in broader and fully formal manufacturing shows that fully formal gazelles reach significantly higher levels of sales per worker, and increase their productivity faster than in total manufacturing. However, they provide no more than one tenth of all jobs in the fully formal sector.

Figure 11. - Gazelle firms in fully formal versus total manufacturing Sales per worker, thousand TRY, 2003 prices
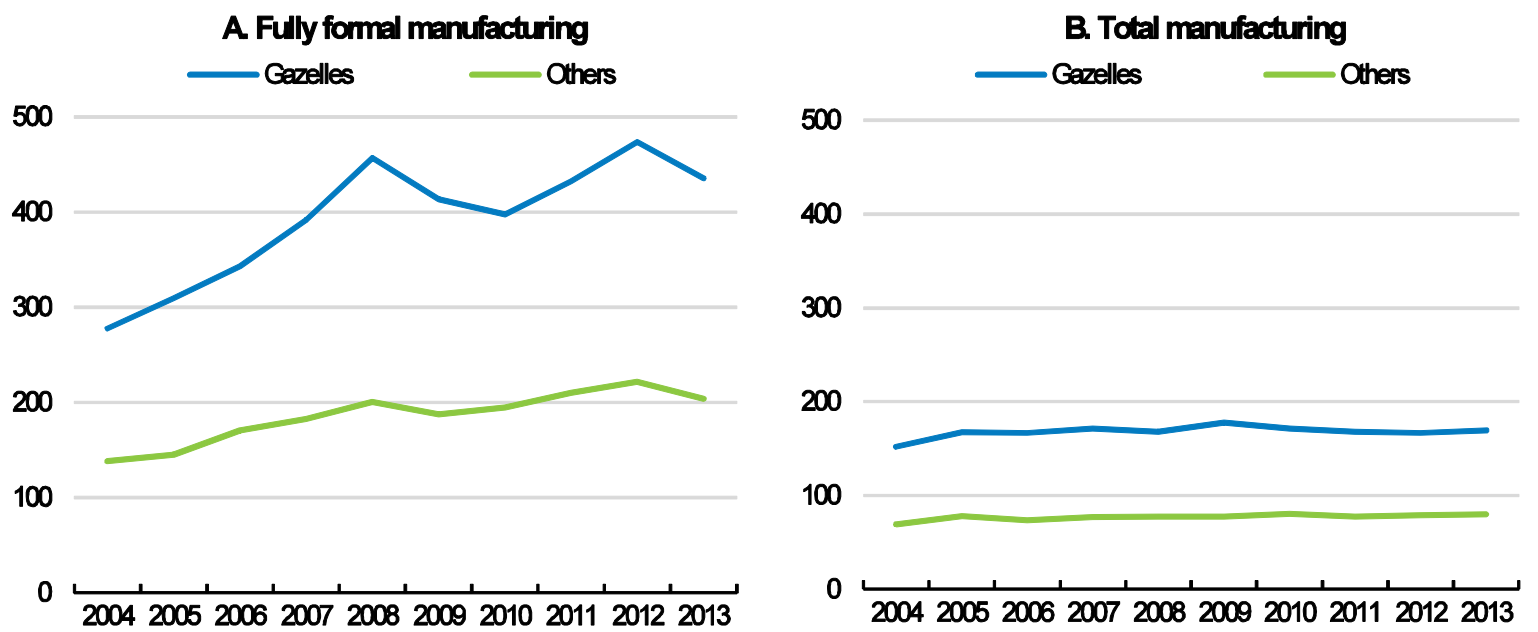

Source: Turkish Statistical Institute; Central Bank of the Republic of Turkey.

Foreign direct investment (FDI) firms are another well-performing group, but cannot be identified separately in the data sets of this survey. Even when defined traditionally (firms with at least $10 \%$ of foreign voting share) they have a relatively limited weight in Turkish manufacturing (OECD, 2014a). Nonetheless, they have knitted thorough relations with the local industry, including via small shareholdings and technological partnerships, and generate substantial productivity spillovers for local partners (Atiyas and Bakış, 2015).

\section{The fully formal sector is not developing at full potential}

Fully formal enterprises do not appear to expand at full potential in Turkey. Three types of obstacles dent their growth: they face particularly penalising labour regulatory restrictions; family firms among them are too slow in becoming financially transparent and modernising their corporate governance arrangements; and FDI and large domestic firms face a number of basic shortcomings in their business environment.

\section{Constraints arising from labour regulations}

Between 2003 and 2013, employment has grown at 3\% per annum on average in the CBRT database's fully formal firms, as against a pace of over 7\% in the broader Turkstat database. Improvements in firm coverage in both databases partly explain these growth rates, but fully formal firms indeed seem to create fewer jobs, while the broader manufacturing sector achieves slower productivity growth and seems to create the bulk of new net jobs outside the fully formal segment. Considering that larger-size firms in the Turkstat database are formalised in a higher proportion than small and medium-sized firms, the decline of the employment share of large firms in this database from 35\% in 2003 to $28 \%$ in 2013 supports this assumption. 
Comparatively slower job creation by formal firms may result from the regulatory framework they are subject to. As discussed in detail in the 2014 OECD Economic Survey, Turkey has some of the most rigid labour market regulations in the OECD, which curb market entry and investment incentives of law-abiding firms (OECD, 2014a). Impacts seem to be more strongly felt in labour-intensive activities, as can be seen in a quantitative assessment of labour allocation efficiency in Turkey's labour-intensive and non-labour intensive sectors (see Atabek et al., 2016): this difference is larger in Turkey than in OECD economies with less rigid labour regulations. It is estimated that if Turkey's labour market regulations converged to OECD best practices, the level of labour productivity in labour-intensive manufacturing may increase by roughly $30 \%$, lifting aggregate labour productivity in the manufacturing sector by up to $15 \%$.

The extension of this analysis to product market regulations reveals similar - but narrower - negative effects on fully formal manufacturing (Atabek et al., 2016). Restrictions to product market competition, discussed in the previous Economic Survey (OECD, 2014a), are found to be detrimental to labour allocation efficiency in activities characterised by high entry and exit rates. Better convergence of product market rules with OECD best practices would generate productivity gains in these sectors, and as a result in total manufacturing.

\section{Family firms do not formalise swiftly}

Family firms throughout Turkey have contributed to the broad-based growth of manufacturing in the 2000s. Enterprises employing less than 250 workers have expanded fastest. The large majority of these firms are family-owned. The more successful ones are relatively more formalised than others, but even they face hurdles when modernising their governance arrangements and accessing the capital market, i.e. the stock exchange. Their challenges become evident in intergenerational transmissions. According to the Corporate Governance Association of Turkey, the average life expectancy of family firms is 34 years and only $30 \%$ of them continue to operate successfully after a generational change (Girişim Haber, 2016). A survey of the board composition in the Istanbul Chamber of Industry's " 2 nd 500 " list of firms, which are representative of successful medium-sized family enterprises in Turkey, revealed that, as of 2014, $42 \%$ of them had not a single board member from outside the family (Sak, 2014). This is in tune with international research findings suggesting that "delegation costs" (lack of trust and judicial inefficiency) hinder the professionalisation and upscaling of family-owned firms in other emerging countries (Bloom et al., 2011).

The need for formal boards and professional managers increases as family businesses expand. The average Turkish firm is behind compared to other OECD countries (Figure 12). Absent progress, closed governance practices may deter productivity diffusion through two channels: "within enterprise" gains slow down if family firms lack incentives from boards to maximise efficiency, and "between enterprise" gains are hindered if successful firms refrain from growing in order to preserve family control.

Delays in the formalisation of governance arrangements and the professionalisation of management slow down progress in financial transparency. Currently, financial statements according to international standards are only available for the minority of stock market-listed firms, and for the firms of regulated sectors (which are compelled to produce audited accounts). As of early 2016, only 80 out of the top 500 and 120 out of the top 1000 firms were listed on the stock exchange. A new Commercial Code prescribes the issuance of such accounts by all firms under formal external auditing, but the enterprise size at which this rule will apply is not yet settled.

Closely-held firms' reluctance to enhance their transparency may also be related to tax considerations (OECD, 2014a). Turkey's corporate income tax revenues, reached only 1.8\% of GDP in 2014, against an OECD average of about $3 \%$, despite a statutory corporate income tax rate of $20 \%$ in Turkey compared to an average of about 25\% in the OECD (OECD, 2016b), pointing to low tax compliance. Other possible reasons are below-average corporate profits and a narrow corporate income tax base as a result of above- 
average tax deductions. Many non-listed enterprises may be averse to financial transparency in order to minimise tax liabilities.

Transparency is essential to improve access to capital and so is better corporate governance (Dünya, 2016c). Overall, previously less formal firms start to become more transparent and gain better access to bank credits. The stock of outstanding SME loans increased from TRY 204 billion in 2012 (15\% of GDP) to TRY 338 billion in 2015 (17\% of GDP) (BRSA, 2016). Non-debt financing channels also started to expand, although from low levels, through private equity networks and the listing of firms in the newly created "emerging firm" and "special investment" markets of the Istanbul Stock Exchange. Public policies seek to stimulate these developments through tax incentives to equity issuance (from 2015, a deduction from taxable corporate profits, calculated by imputing a notional rate of return on newly issued equity, has aimed at reducing the tax bias between debt and newly issued equity, see OECD, 2016b), a business angel support scheme, and, most recently, a Turkish Growth and Innovation Fund. This is a "fund of funds" backed by the European Investment Fund, which will place at least EUR 400 million in mostly foreign but also domestic funds investing in venture businesses in Turkey. Additional resources are also being made available, including via Treasury participation in a Turkish Investment Fund with a planned investment capacity of EUR 48 million. The effectiveness of public support schemes for risk capital is debatable (Andrews and Criscuolo, 2013), but the advent of these instruments implies that small and medium sized firms with high potential will have wider access to additional funding sources and management support in the future, provided that they improve governance structures, enhance financial transparency, and upgrade from semi-formal to formal status.

Figure 12. - Room for progress in corporate governance

2014, score from 1 (worst) to 7 (best)

A. Eficacy of corporate boards

6

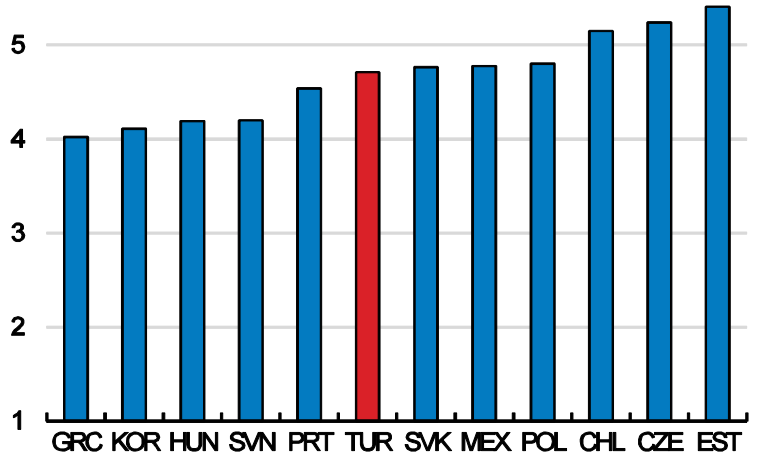

B. Reliance on professional management

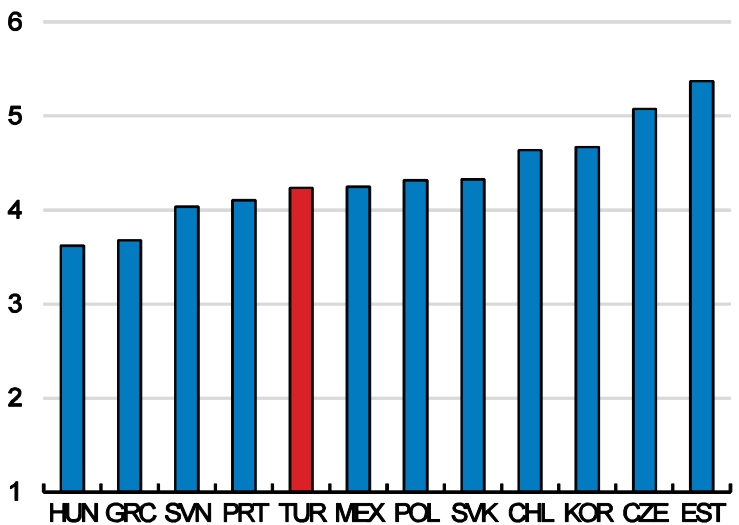

Source: World Economic Forum, Executive Opinion Survey

\section{Very large firms and FDI are undersized in international comparison}

The most formal part of the manufacturing sector, i.e. stock market-listed and FDI firms, is smaller in Turkey than in other catch-up OECD economies (Figures 7 and 1.14). The 2014 OECD Economic Survey had highlighted their high productivity performance (OECD, 2014a). The individual size of stock marketlisted firms is small in international comparison, and has increased more slowly than in other countries since the mid-2000s (Figure 13, Panel B). The aggregate share of listed manufacturing firms is also smaller, and has tended to contract slightly over the past decade, while it increased in other countries (Figure 13, Panel A). 
Listed manufacturing firms have invested more in financial assets over the past decade than their international counterparts, rather than expanding productive capital (Figure 14 Panel D). Combined with the low stock of manufacturing FDI, such underinvestment by more advanced firms slows down the reallocation of resources to the higher productivity side of the economy.

Surveys suggest that the fully formal firms are particularly sensitive to the integrity of basic governance in their business environment. Excessive prevalence of informality, corruption and political instability are systematically reported in surveys in Turkey as being particularly discouraging for this type of firms (Figure 14, Panel A).

Figure 13. - Room for more growth by fully formal firms

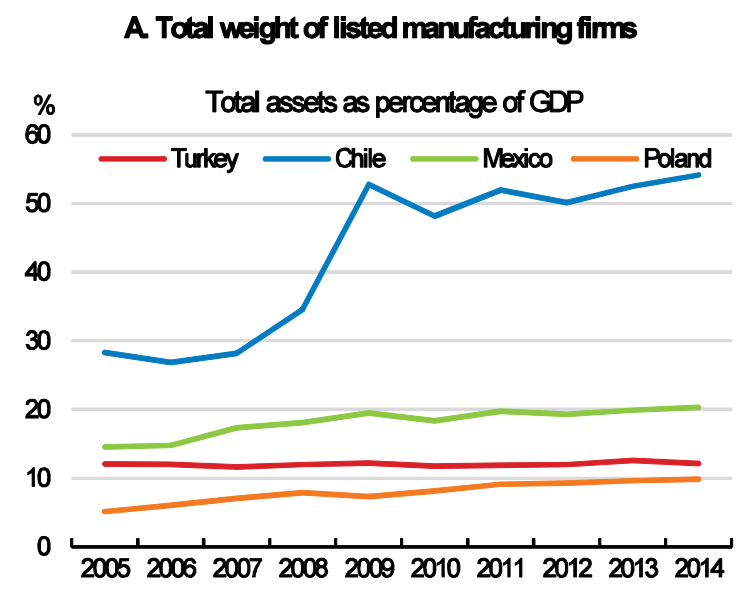

\section{B. Median size of listed manufacturing firms, 2014}

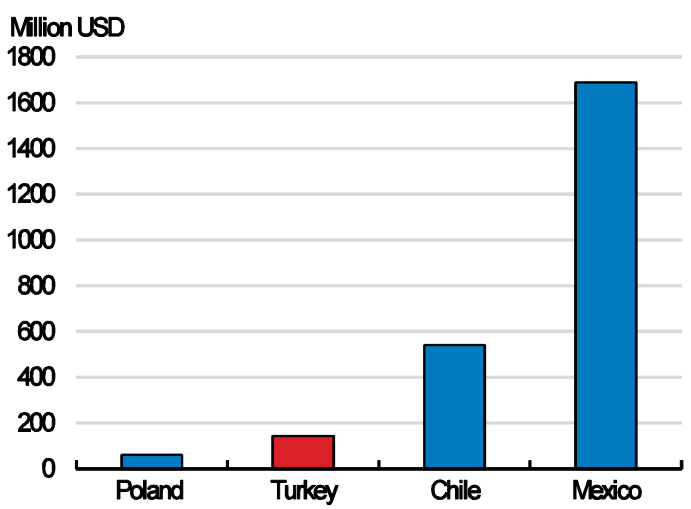

C. Real assets of median listed manufacturing firms
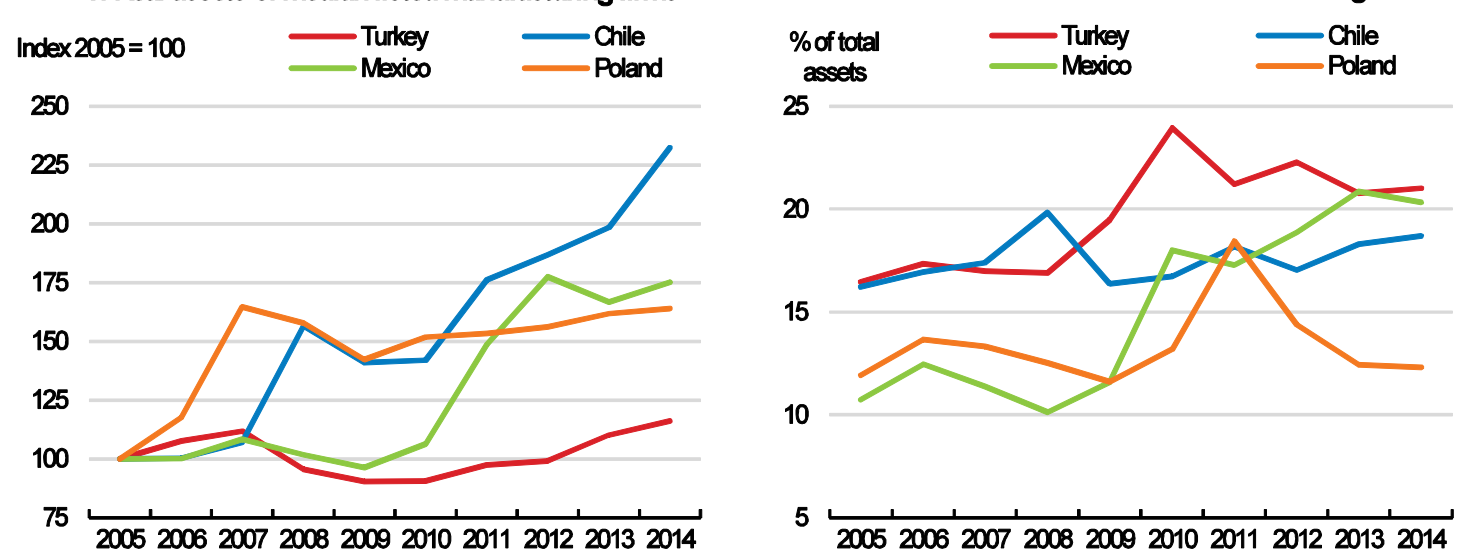

Source: Thomson Reuters Datastream; OECD calculations.

\section{Sophisticated start-ups are penalised by shortcomings in the business environment}

Small, human capital-intensive formal businesses are also very sensitive to the integrity of their basic governance environment. As newcomers and outsiders in the market, they are less able than incumbents to remedy to the pressures arising from illicit practices, non-level playing competition and political unpredictability. Their aversion to informality, corruption and political uncertainties comes through in surveys (Figure 14 Panel B). More recently, trade associations of traditional small businesses also started to voice grievances about unfair competition from entities flouting the law (Dünya, 2016b). 
Figure 14. - Investment obstacles reported by fully formal firms

Index scale 0 (no obstacle) to 4 (very severe obstacle)
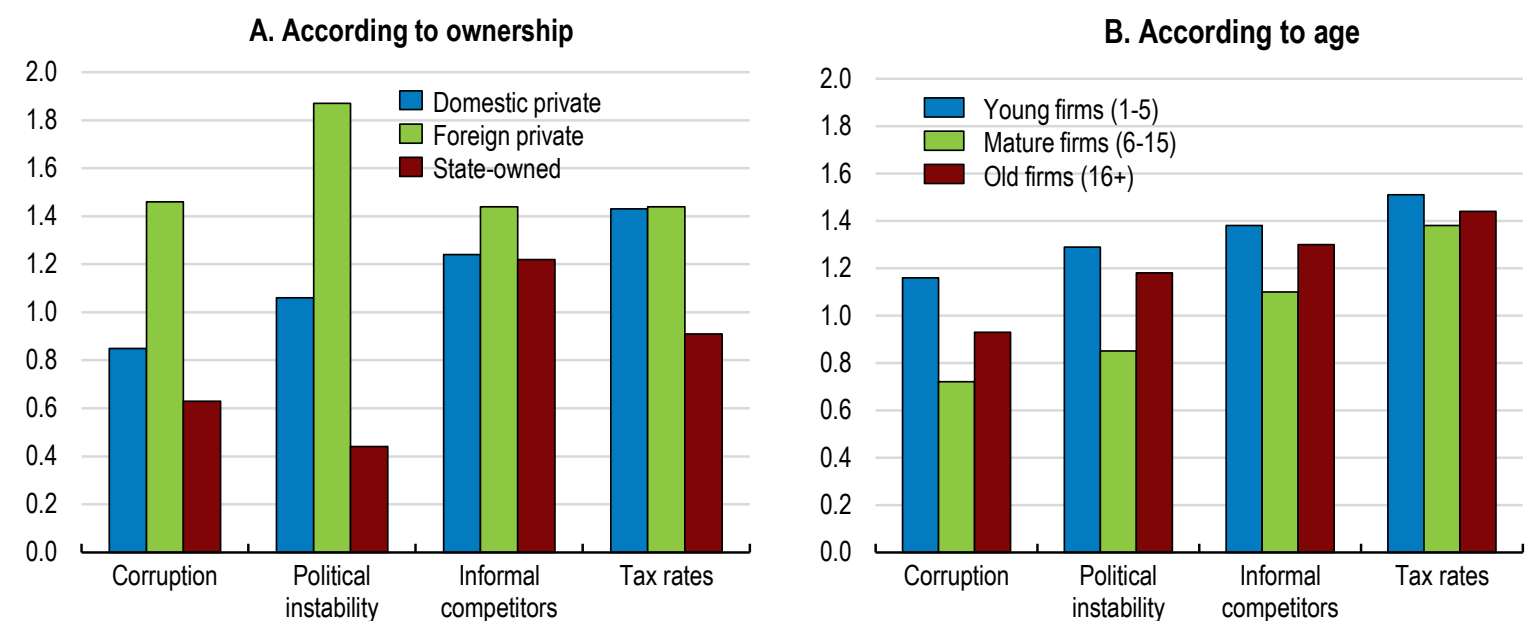

Source: World Bank (2013), Enterprise Survey; and OECD calculations.

\section{Export performance has weakened}

The exported share of Turkey's total added value, at $18 \%$, is the lowest among comparable countries and increased by only one percentage point between 2000 and 2011, lagging behind comparable OECD countries (Figure 15, Panel A). The participation of Turkish firms in global value chains (GVCs) is also below potential (Ziemann, 2016). Data for fully formal enterprises in the CBRT database confirm this weakness in their exporting activity, except in the highest technology segment (Figure 15, Panels C and D).

Weak export intensity hampers macroeconomic rebalancing and signals that firms fail to reap the productivity benefits associated with export orientation. These benefits arise from "learning from exporting", higher economies of scale and acceleration of technological change (Yang and Mallick, 2010; Isgut and Fernandes, 2007). Firm-level data show that exporting firms achieve a higher level and growth rate of productivity in Turkey. Recent research has confirmed, after controlling for reverse causality, that Turkish exporters are financially more robust, more productive and more R\&D intensive than nonexporters (Atabek Demirhan, 2015). Among fully formal firms and from a sectoral perspective, exportintensity declined for low-technology and labour-intensive firms but has been on the rise for medium and high-technology firms (Figure 15, Panel D).

Quality enhancement increases value added and is an important dimension of productivity gains. The quality of Turkish manufactured goods has not caught up with comparable countries. Their relative quality, measured by the share of high-value products (i.e. goods with prices at least $15 \%$ above world reference prices) progressed in the first half of the 2000s, but subsequently declined. It was lower than in comparable countries in 2013, at around $10 \%$ in most export sectors. Textiles and clothing is an exception, with about $60 \%$ of high-value products exported, as producers succeeded to position themselves in higher market segments than low-cost countries (Chapter 2, Figure 6). 
Figure 15. - Export intensity has weakened overall, but improved in dynamic areas

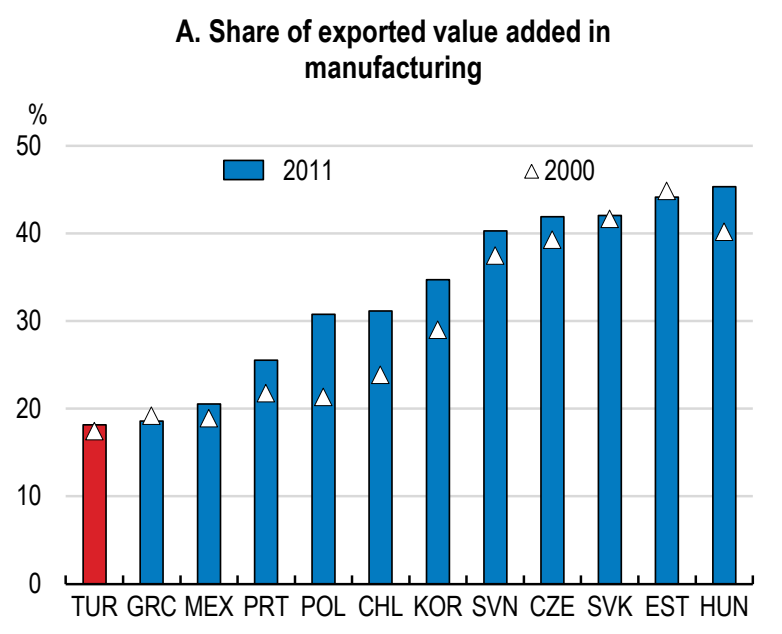

C. Export intensity according to firm size

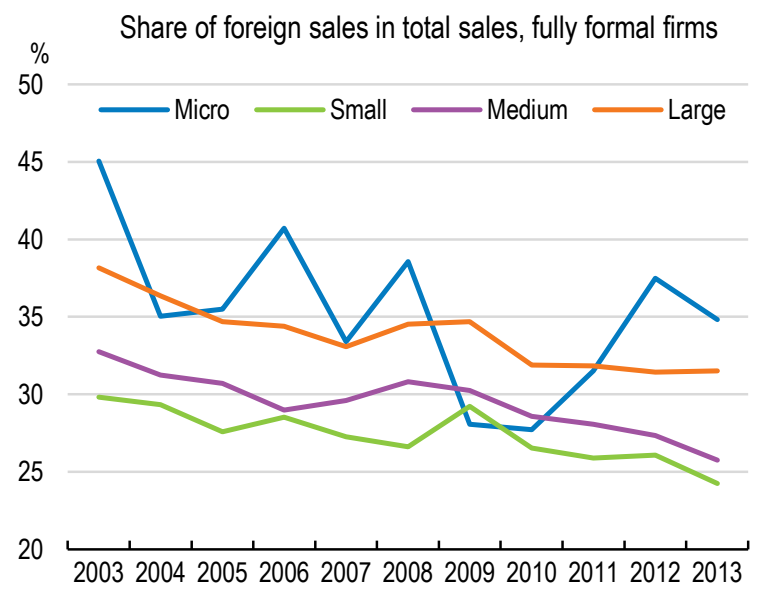

\section{B. Export intensity in fully formal enterprises}

Share of foreign sales in total sales, fully formal firms 40 35

30

25

20

20032004200520062007200820092010201120122013

\section{Uneven export orientation according to} industry types ${ }^{1}$

$\%$

Share of foreign sales in total sales, fully formal firms

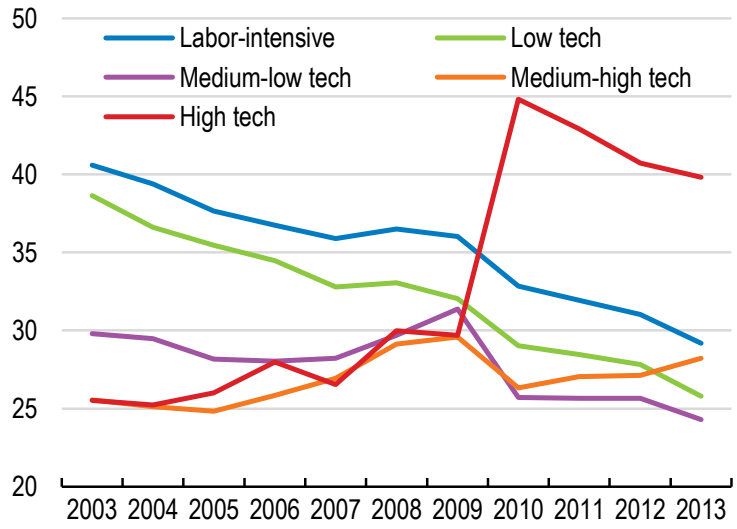

For the definition of industry types, see Figure 5.

Source: OECD/WTO (2016), "Trade in value added", OECD-WTO: Statistics on Trade in Value Added (database), DOI: http://dx.doi.org/10.1787/data-00648-en; Central Bank of the Republic of Turkey; and OECD calculations.

\section{Labour allocation is particularly poor in labour-intensive industries}

The contribution of the allocation of employment between firms to the level of productivity results from two effects: i) the productivity distribution of firms (i.e. the fraction of high-productivity relative to low-productivity firms); and ii) the extent to which, all else equal, high-productivity firms command a larger share of aggregate employment. This decomposition was applied in OECD work on the basis of "sales per worker" information (Andrews and Cingano, 2014). Its extension to Turkey suggests that labour is not allocated as well in Turkey as in other OECD countries. The actual allocation of labour across firms boosts manufacturing labour productivity by around $15 \%$, relative to a baseline in which labour would be allocated randomly across firms. These allocative gains exceed 60\% in the United States and 40\% in Japan (Figure 16, Panel A). 
Labour allocation is particularly poor in labour-intensive activities, especially in the fully formal sector. As discussed above, this may be related to rigid labour regulations being more binding for ruleabiding firms. Once labour-intensive activities are removed from the calculations, estimated labour allocation efficiency improves both among fully formal firms and in total manufacturing. As discussed in Appendix 1, it comes close to EU averages, but stays below estimated allocative efficiency in the United States and Japan (Figure 16, Panel B).

Figure 16. - Resource allocation efficiency in total and fully formal manufacturing Productivity gains, percentage

A. Resource allocation efficiency

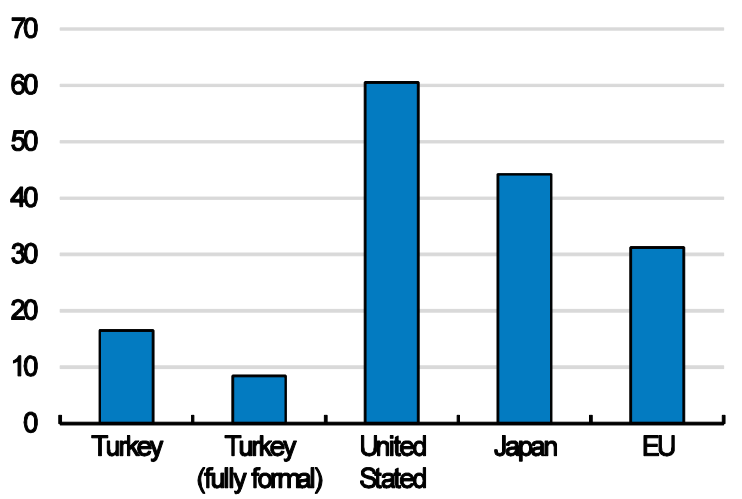

B. Resource allocation efficiency in Turkey's labour intensive and non-labour intensive sectors

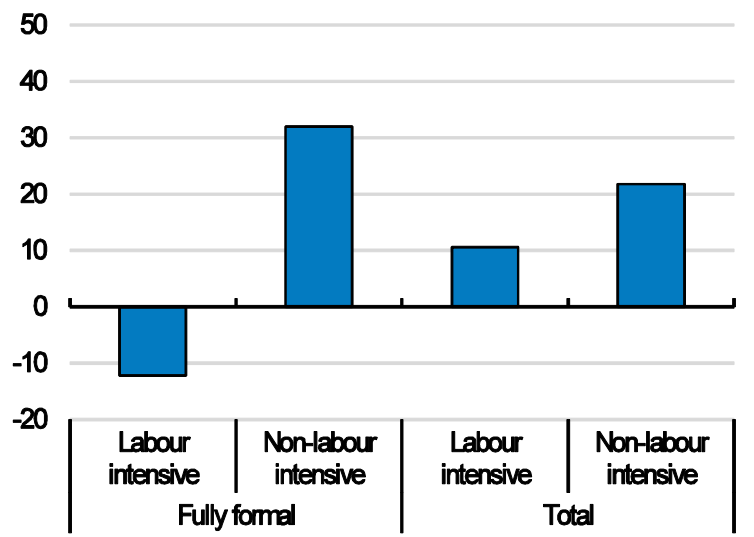

1. Increase in productivity, compared to unweighted average productivity. 2013 for Turkey, latest available year for others.

Source: Andrews and Cingano (2014), "Public Policy and Resource Allocation: Evidence from Firms in OECD Countries", Economic Policy, No. 78; OECD calculations based on 2013 data from Turkish Statistical Institute and Central Bank of the Republic of Turkey.

\section{Formalisation requires a coherent policy framework}

Improved productivity performance requires low-productivity firms to be better equipped to catch up with higher-productivity ones, and higher-productivity firms to be better incentivised to grow at their full potential. This section reviews some of the policy areas that influence these outcomes. A coherent strategy to make progress in these areas would help upgrade the business environment for all firms, be they fully formal or not. Firms of all types, sizes, sectors and regions can then achieve stronger productivity gains and the best performing firms can grow more freely and rapidly.

The section starts with the industry-relevant measures of the 2016 Action Plan of the previous government. Table 2 lists measures which were envisaged in education, labour markets, R\&D and other regulatory areas, and which carried a potential to stimulate productivity and employment growth in the manufacturing sector.

Public policies in five areas have a particularly important impact on the capacity of existing firms to catch up with higher productivity firms, and for the capacity of higher-productivity firms to absorb a higher share of the labour force. These areas concern: i) worker skills and the flexibility of the labour force; ii) financial transparency and corporate governance; iii) availability of a "diffusion-oriented" R\&D infrastructure; iv) the quality of service inputs; and v) a supportive macroeconomic and rule-of-law framework. Recent developments and further reform requirements in these areas are discussed below. 
Table 2. Industry-relevant measures of the 2016 Action Plan

(Numbers in brackets refer to the reference number of each measure in the Plan)

\section{EDUCATION}

A National Education Quality Framework and an Education Quality Index to be introduced for all levels of education (Measure 131). The curricula at all levels of education to be updated (Measure 130).

Foreign language education to be strengthened (Measure 132).

The administration of vocational and technical schools to be reformed (Measure 134). Vocational and technical schools to be restructured and upgraded for stronger links with the labour market (Measure 135).

The compatibility between curricula in vocational schools and job specifications in labour markets to be improved (Measure 40). The infrastructure for apprenticeship training to be strengthened (Measure 136). Additional support to be granted to private vocational schools established outside Organised Industrial Zones (Measure 45).

\section{LABOUR MARKETS}

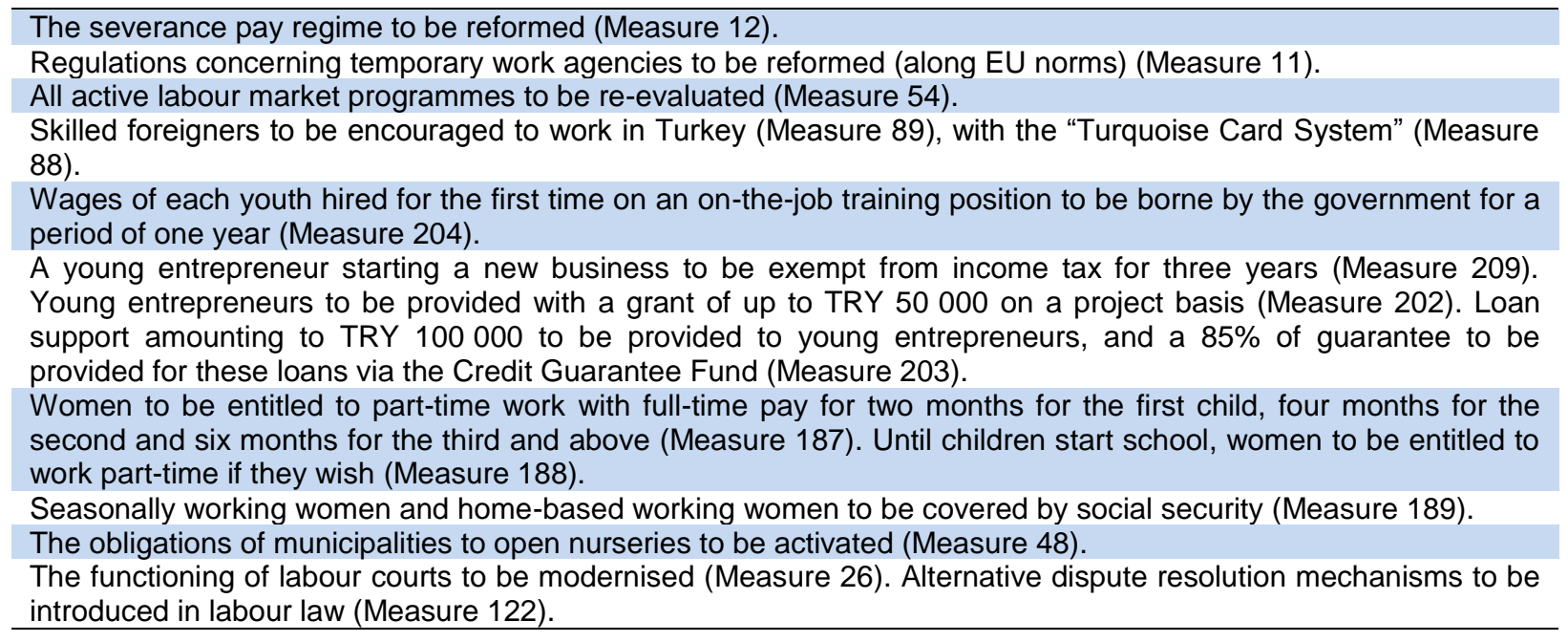

\section{RESEARCH \& DEVELOPMENT}

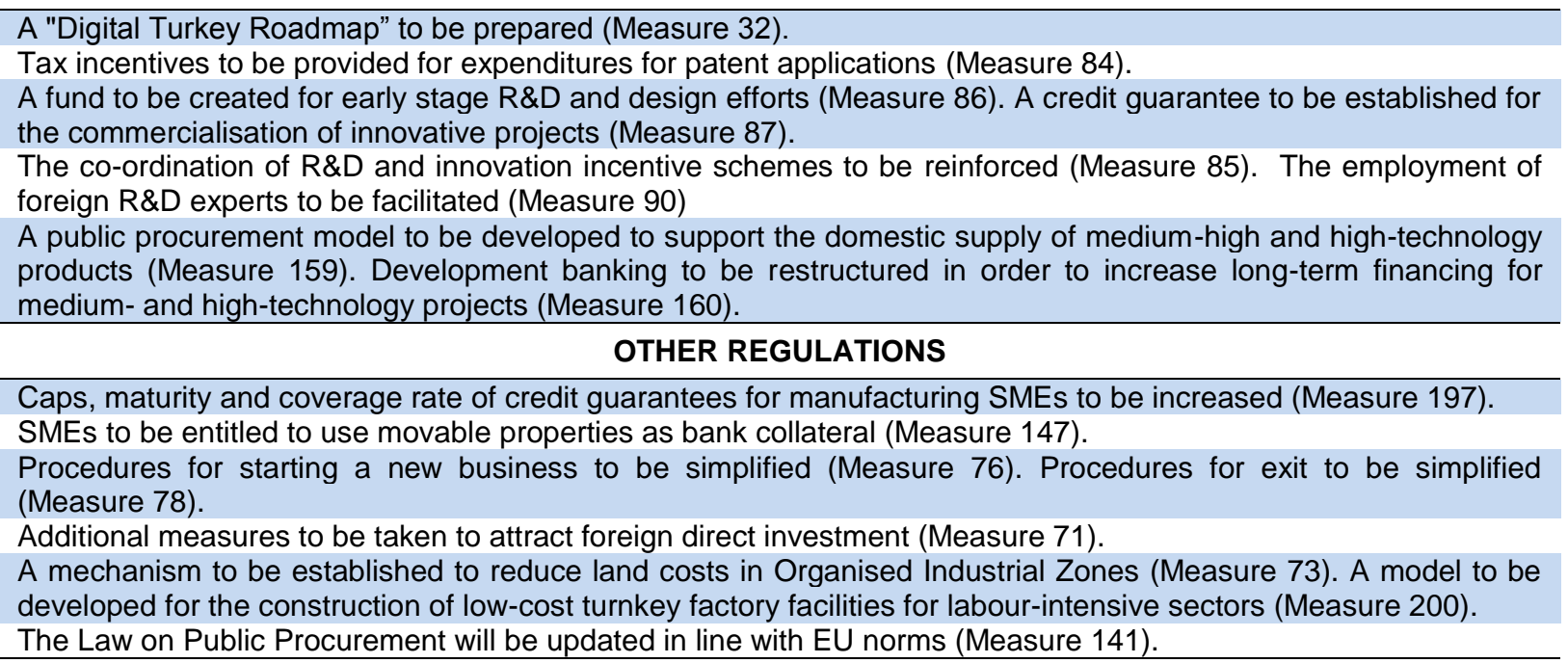

\section{Upgrading skills and reallocating labour}

The Public Employment Service (Iskur) and the SME Agency (KOSGEB) have already expanded their upskilling programmes. KOSGEB's total budget is tripling in 2016, to TRY 990 million. Iskur offers wage and social security subsidies for on-the-job training of new recruits and 370000 participants attended these programmes in 2015. Given the low education level of the bulk of the working age population and 
extensive needs for requalification (as will be shown in the OECD/PIAAC Survey of adult skills to be published in 2016), special attention ought to be paid, in the process of productivity-enhancing structural changes, to the basic managerial skills of small entrepreneurs and to the re-employment prospects of lowskilled employees exiting low-productivity firms.

Raising the management know-how of hundreds of thousands of low-educated small entrepreneurs may bring about significant "within" productivity gains. International experience suggests that welldesigned programmes can yield high returns (OECD, 2002; McKenzie and Woodruff, 2015). Successful international precedents should be screened, the impact of existing programmes should be appraised, and resources concentrated on the most effective schemes. Basic English training may be part of this agenda, to enable small entrepreneurs to access the international knowledge and market platforms via internet (Koru and Akesson, 2011). According to the 2015 EF Proficiency Index, average English proficiency is very low in Turkey, which ranks $43^{\text {rd }}$ among 44 countries. A recent study found that, around the world, $70 \%$ of external communications of an average firm with export activities is carried out in English, and, in globalised firms, $65 \%$ of internal communications take place in English (Karaboğa, 2016). Turkish firms, except the largest and the most internationalised ones, are thus at a disadvantage.

The transfer of low-skilled workers from lower to higher-productivity firms is also key. This can be facilitated by upskilling workers. Additional support was expected from the 2016 Action Plan for the onthe-job training of new recruits. However, policy support in this area may also be mis-used as a generous employment subsidy, rather than for effective retraining. All related programmes, old and new, should be evaluated on a longitudinal (medium term) basis.

Excessive restrictions in Turkey's employment rules and overly high labour compensation costs have hindered the institutionalisation of SMEs and the growth of formal firms (OECD, 2014a). A far-reaching labour market reform to bring employment rules closer to OECD good practices has always been a top priority (OECD, 2006a; OECD, 2010a). In this area, the 2016 Action Plan envisaged to build on the sensible National Employment Strategy which was elaborated (but not implemented) in 2014. The 2016 Plan targeted rapid progress in the implementation of the strategy and as of May 2016 a law starting to liberalise temporary work agency services was adopted. Current efforts in reforming the severance pay system require broad support across stakeholders including unions and business organisations.

The full range of modern employment forms in use in OECD countries should be made available in Turkey. These include renewable fixed-term contracts, temporary work agency contracts, outsourcing, part-time work, and working from home. So far such flexible forms were merely accessible to informal and semi-formal firms, and they should become available to institutionalised firms. The new law adopted in May is a welcome first step. The severance payment regime (practically available only to a minority of workers in the formal sector) should also be replaced with "portable" severance saving accounts along the lines of the system in place in Austria (Hofer, 2006).

New employment forms would enable firms to create new jobs according to cyclical and market demands, rather than expanding the work hours of existing workers. This well-being reducing feature of the Turkish labour market is due to regulatory rigidities. With reforms, part-time work would also become easier and would help better mobilise low-activity groups (Akdemir, 2016).

Employment costs of low-skilled workers should be reduced in the formal sector. Official minimum wages were already above those in comparable OECD countries before the $30 \%$ increase granted in January 2016. Turkey had the OECD's highest minimum/median wage ratio at about $70 \%$, and this ratio is projected to increase in 2016 despite the expected increase in the general wage level. Combined with high employer social contribution rates, total labour costs for low-skilled workers are too high to sustain 
sufficient demand for their services in the formal sector, as confirmed by recent simulations (World Bank, 2014). Reducing labour costs on a large scale may significantly increase employment.

The temporary government subsidy of TRY 100 per worker per month granted to the employers of minimum wage earners offsets up to $40 \%$ of the latest increase in their costs (IMF, 2016) during the first year. Going forward, the government and the social partners in the Minimum Wage Commission should moderate across-the-board increases in the official minimum wage, and take into account regional and enterprise circumstances. The large productivity gaps and divergences between firms, including within the fully formal sector, call for a decentralised approach.

At the same time, the security leg of the flexicurity strategy should be reinforced. The scope and eligibility for unemployment insurance should be broadened to better move protection from jobs to individuals. According to a recent OECD assessment (Andrews and Saia, 2016) achieving this by upgrading active labour market policies rather than passive income support would make a large difference for labour supply. Recent increases in social transfers appear to have weakened work incentives in some labour market segments. For able working age individuals, these transfers should be made conditional on labour force participation and supported by effective upskilling schemes.

\section{Financial transparency and corporate governance}

It is important to preserve the financial incentives of new business start-ups throughout the country, which helped stimulate the broad-based development of export-oriented manufacturing in the 2000s. However, the moderation of tax pressure on entrepreneurs should not be obtained through weak tax administration and widespread tax evasion (which benefit informal and low-productivity businesses) but through properly designed tax rules that encourage investment, innovation and job creation by all firms (OECD, 2015b; OECD, 2010b). Installing a tax system that includes both "carrots" and "sticks", and incentivising informal businesses to enter the formal economy will be essential. The government submitted a draft tax law to Parliament in mid-2013 to unify and streamline the Personal Tax Law and the Corporate Tax Law into a simpler income tax legislation (Vergi Portal1, 2016). An in-depth review of the current design of the tax system would be welcome with a view to, for instance:

- Minimise the tax cost of firms shifting from the so-called "simplified" to the normal tax regime. This would remove one obstacle to the formalisation of SMEs.

- Maintain strong incentives for all firms to undertake productivity-enhancing investments and create high-quality jobs. The extension, in 2015, of R\&D tax incentives to design activities at large, and the introduction, in 2016, of a multi-year tax exemption for young entrepreneurs had this objective. The effectiveness of these schemes should be evaluated.

The ongoing introduction of compulsory external audits for all firms should be carefully managed. Size thresholds at which higher degrees of transparency will kick in have not yet been finalised. These thresholds should be high enough not to discourage the formalisation of smaller firms, or be combined with measures reducing their compliance costs.

Stepping up the formalisation of medium-sized family firms would also accelerate productivity gains. Expected governance improvements from outside equity injections, via private and angel capital placements and stock-market listing are large (OECD, 2015c, Price Waterhouse Coopers Turkey, 2013). Tax measures were taken in 2015 to stimulate external equity rather than debt funding, via tax exemptions for dividend payments and the introduction of an allowance for newly issued corporate equity. The ongoing Istanbul Financial Center Project will include other plans to promote market-based financing. 
Incentives for qualified outside partners to take part in the governance of closely-held firms may help boost productivity. The "business angel" scheme adopted in 2012 (exempting 75 to $100 \%$ of investment by personal investors in private company stock that they hold for at least two years from their taxable income) appears to have stimulated such investments in the past three years (Dünya, 2016c). Angel investments grew reportedly from EUR 14 million to EUR 30 million between 2013-15. The long-term tax costs and actual investment outcomes of this generous incentive should be monitored. Effective competition policy in innovation-intensive areas would enhance the survival probabilities and the growth prospects of startups, helping attract more private capital to them, and would reduce the need for direct public support.

\section{A “diffusion-oriented" R\&D infrastructure}

"Mission-oriented" innovation policies aim at promoting R\&D projects of national significance, whereas "diffusion-oriented" programmes aim at upgrading the capacity of firms to absorb frontier technologies. Turkey's R\&D policies which expanded in the 2000s focused initially on national missions (in the areas of defence, space observation, health technologies, etc.). More recently, R\&D incentives have been re-oriented to diffusion objectives. A higher share of the public R\&D budget is allocated through tax incentives, and less through direct subsidies. In early 2016, an additional R\&D support package provided tax incentives to joint projects between firms and university researchers (offering secondment opportunities and tax exemptions to researchers temporarily joining enterprises). The results of these initiatives should be monitored and the "diffusion" leg of the R\&D system should continue to be reinforced.

The instruments of $R \& D$ support should be reassessed in the light of domestic and international experience. According to recent OECD research, both tax incentives and direct subsidies, if poorly designed, may favour incumbents and discourage new entrants( (Andrews and Criscuolo, 2013). Design features are crucial to minimise the fiscal cost and to maximise the social benefits of these policies. In Turkey, the establishment, by the Ministry of Science, Industry and Technology, of an impact assessment department was a welcome initiative. Together with the planned implementation of the state aid monitoring system from end-2016, it is expected to enhance the understanding of the impact of $R \& D$ and innovation policies. These evaluation studies should be regularly published.

Potential gains from diffusion-oriented R\&D and associated technical extension services are important in the area of "Industry 4.0". There is wide scope in Turkey to reap productivity gains from broad-based digitalisation (World Bank, 2016). Surveys on the early diffusion of these techniques in Turkey reveal that firms with sophisticated human capital have taken an edge (Findik and Tansel, 2015). If this gap between different categories of firms were to become a lasting divide, it would deprive the economy from broad-based productivity convergence and worsen the already large productivity divergences between firms.

Many commercial operators (suppliers, consultants, banks etc.) market related techniques and services in Turkey. Public services helping disseminate relevant knowledge for various users (small businesses, agriculture, etc.) could support this process. The SME Agency KOSGEB, in co-operation with universities and international partners, could lead this technical extension function.

Synergies between firm-level digitalisation (Industry 4.0), digitalisation of interactions with the public sector (e-government) and digitalisation of transactions with business partners (suppliers, customers, banks, investors) should be more actively exploited. For example, Turkish exporters see room for the integration of their information and management systems with the trade recording systems of the Ministry of Finance and of the Ministry of Customs (Dünya, 2016a). An application planned by the Ministry of Finance is an electronic register for individual firms' movable assets, which should permit their utilisation as collateral by banks (Şimşek, 2016b). The diffusion of these techniques, however, requires that 
entrepreneurs and firms be confident that the greater transparency implied by integrated digitalisation will not in practice amplify their tax liabilities.

\section{The quality of service inputs}

Services provide important inputs to manufacturing in all OECD countries (Nordas and Kim, 2013). Efficiency gains in existing firms, as well as the growth of successful firms rely on services in the areas of finance, engineering, consulting, marketing, logistics, etc. The interaction between service suppliers and their manufacturing customers seems to fall short of international standards in Turkey in three areas, calling for remedial measures:

- Network services provided by state-owned and recently privatised monopolies are generally more expensive and/or of lower quality than in other OECD countries. This is the case in electricity supply and railway transportation. More proactive competition reforms and more efficient regulations would help upgrade performance in these areas.

- Several professional services are closed to international trade and investment. OECD service trade restrictiveness indicators (STRIs) show this to be the case in accounting, legal and various logistics services (OECD, 2015d). These areas should be liberalised in order to give Turkish manufacturers access to world quality services. An OECD Competition Assessment Review could help with the prioritisation of such reforms.

- Transport infrastructures are crucial for the timely and low-cost delivery of Turkish goods to domestic and foreign markets. This is important in particular for the suppliers integrated in global value chains (Chapter 2). A severe challenge stems from the restrictions and quotas applied to Turkish road freight transporters in international, and in particular European, markets. This was recognised as a major issue in a recent study on the smooth operation of the EU/Turkey Customs Union (World Bank, 2014) and ought to be addressed in the forthcoming round of negotiations on the updating of this agreement.

A particularly important source of services for manufacturing firms are organised industrial zones (OIZ). OIZs have been expanding in Turkey since the 1980s. They received large in-kind subsidies from the government, which may have diverted investment away from other locations. Still, they considerably facilitated infrastructure and other service provision, and stimulated knowledge diffusion (Bozkurt, 2016; Gungor, 2016). In 2015, 284 OIZs were in operation, hosting over 40000 industrial establishments and 1.53 million workers (more than 30\% of total manufacturing employment in Turkey) (Ișik, 2015). According to one calculation, $70 \%$ of the new manufacturing jobs created between 2009 and 2014 were created in OIZs (calculated as the difference between manufacturing employment reported in OIZs by two official sources in 2009 and 2014 - TESEV, 2009 and Işık, 2015).

OIZs stem from local private sector initiatives, usually led by local associations of entrepreneurs that have been granted public land. They offer member firms physical infrastructure, as well as logistics and transportation, communication and energy, environmental management, vocational training and other technical services. Participants are in general formal enterprises which pay substantial membership fees. They comply with common rules, and informal employment is generally limited.

OIZs leverage the productivity of participating firms. In the past decade, sectoral OIZs started to be developed, in areas such as leather processing, shipbuilding, car components, agro-food production, etc. They provide sector-specific services to their members, including vocational facilities, measurement and test infrastructures, etc. and nurture the emergence of specialised clusters. The government seeks to further spur the growth of OIZs. The Minister of Science, Technology and Industry declared recently the goal of raising the share of manufacturing employment in OIZs to above 40\% (Işsk, 2015). The 2016 Action Plan implied that OIZs would be granted additional public land, and possibly additional subsidies for their 
construction costs. One goal was to facilitate the upgrading of the so-called "small industry sites" which were supporting small and micro businesses with less advanced infrastructure (457 small industry sites were in activity in 2015, hosting more than 90000 small businesses and nearly 500000 workers) into fully-fledged OIZs.

The effectiveness of OIZs depends on how supportive their own business environment is. There is evidence that successful OIZs may become vulnerable to predatory taxation and service over-pricing by local authorities (Tuncay, 2016; Y1ldırım, 2016). They should be subject to clear and transparent tax rules, and dependable service provision contracts by municipalities. As well, government support to OIZs, including land allocations, should be provided transparently, to nurture level-playing competition between them. Public support can be made proportional to the productivity-enhancing services that they provide, such as vocational schools, life-long learning facilities, and technical extension services.

\section{A supportive macroeconomic and rule-of-law framework}

The successful growth of the export sector calls for a sufficient degree of predictability and stability in price competitiveness. Turkey has a flexible exchange rate regime, but overly volatile and, at times, substantially over- or under-valued exchange rates. This volatility increases business risks for investors in the tradable sector. Maintaining the real exchange rate on a sustainable path requires: i) overcoming inflation inertia and achieving lower single-digit inflation, in accordance with the official inflation target; ii) reducing the volatility of the nominal exchange rate by improving and stabilising the risk perceptions of international investors; and iii) implementing supply-side reforms and active competition policies in market areas where prices are excessively sticky and undermine the competitiveness of the manufacturing sector.

There is ample potential in Turkey for further growth of high-productivity large-size firms, and additional FDI by global manufacturing players. These actors engage in long-term and indivisible investments and are particularly sensitive to the stability, quality and predictability of their business environment. According to several surveys, they have perceived improvements in the quality of Turkey's business environment in the early to mid-2000s, but a deterioration since in international comparison. Some key priorities include:

- The judiciary system should operate more dependably and efficiently, with an assurance of full independence.

- An active anti-corruption strategy is needed. This strategy can draw on the recommendations made by the OECD Working Group on Bribery in its monitoring of Turkey under the AntiBribery Convention (OECD, 2014b).

- Competition policy and state aid transparency should be improved.

- Public procurement rules should be reformed to improve openness to competition. EU rules may serve as blueprints. Reforms should cover all types of public procurement, including publicprivate partnerships. 


\section{Policy recommendations}

\section{Recommendations to rebalance the economy by strengthening the manufacturing sector}

\section{Key recommendations}

- Fully implement the reforms of the 2016 Action Plan and enact systematic monitoring and reporting on actual implementation.

- $\quad$ Strengthen the rule of law, judiciary independence and the fight against corruption.

- Reduce barriers to foreign direct investment.

- Encourage minimum wage moderation and reduce labour tax wedges and employment costs for the lowskilled.

- Enhance the flexibility of employment rules for all firms. Avoid tax thresholds for larger and higher-productivity firms.

- $\quad$ Focus upskilling programmes for small entrepreneurs on basic management, foreign languages and digitalisation.

- Improve the social safety net for displaced workers by upgrading active labour market programmes, including those adapted to refugees.

\section{Other recommendations}

- Continue to improve the regulatory framework for doing business, using OECD product and labour market and competition policy indicators as benchmarks.

- Consider an OECD Competition Assessment Review to help in this process.

- Consider a "zero cost licencing" initiative for start-ups.

- Undertake an in-depth review of the tax system to reduce the cost of formalisation and rationalise the tax incentives to $R \& D$, innovation, business angels, industry-university co-operation and other productivityenhancing investments.

- Publish regularly the impact assessment studies of publicly funded R\&D and innovation support programmes.

- Consider creating A Productivity Council with a broad mandate to assess all relevant structural and policy drivers of productivity growth in Turkey and to issue policy recommendations. 


\section{REFERENCES}

Acar, S., L. Kitson and R. Bridle (2015), Türkiye'de Kömür ve Yenilenebilir Enerji Teşvikleri (Coal and renewable energy subsidies in Turkey), International Institute of Sustainable Development, Winnipeg.

AFAD (2013), "Türkiyedeki Suriyeli sığınmacılar: Saha araştırması sonuçları (Syrian refugees in Turkey: Findings from field research)" AFAD, Ankara.

Aghion, P. et al. (2015), "Innovation and top income inequality", NBER Working Papers, No. 21247.

Ahrend, R., A. Goujard and C. Schwellnus (2012), "International capital mobility: Which structural policies reduce financial fragility?”, OECD Economic Policy Paper Series , No. 2, OECD Publishing, Paris.

Alper, Y., Ç. Değer and S. Sayan (2012), “2050’ya Doğru Nüfusbilim ve Yönetim: Sosyal Güvenlik Sistemine Bakış (Social Security system in the light of demographic trends to 2050)", TÜSİAD, Istanbul.

Andrews, D. and F. Cingano (2014), "Public policy and resource allocation: Evidence from firms in OECD countries", Economic Policy, April.

Atun, R. et al. (2013), "Universal health coverage in Turkey: Enhancement of equity”, The Lancet, Vol. 382, No. 9886.

Avşar Kurnaz, Ş. (2009), “Türkiyede Çocuk Yoksulluğu (Child poverty in Turkey)”, Başbakanlık Sosyal Yardımlaşma ve Dayanışma Genel Müdürlüğü Uzmanlık Tezi, Ankara.

Azevedo, J. and A. Atamanov (2014), "Pathways to middle-class in Turkey", World Bank Policy Research Working Papers, No. 6834.

Barro, R. (2015), “Convergence and modernisation”, Economic Journal, Vol. 125, No. 585.

Başç1, E. and M. Yörükoğlu (2016), "Hükümet'e Enflasyon Hedefinin Aşılmasıyla İlgili Mektup” (Letter to the Government on Inflation Overshooting the Target), 26 January, Central Bank of the Republic of Turkey.

Başkaya S., E. Gülşen and H. Kara (2012), "Inflation expectations and central bank communication in Turkey”, Central Bank Review, Vol. 12, July.

Benkovskis, K. and J. Wörz (2012), "Non-price competitiveness gains of Central, Eastern and Southeastern European countries in the EU market", Focus on European Economic Integration, Q3.

Bloom N. et al. (2014), "The New Empirical Economics of Management", NBER Working Papers, No. 20102.

Botta, E. and T. Kozluk (2014), "Measuring environmental policy stringency in OECD countries: A composite index approach", OECD Economics Department Working Papers, No. 1177, OECD Publishing. 
Canatan, R. and D. Y1ldırım (2015), Rights of Elderly People and Care Services: A Comparative Study between Turkey, Italy and Spain, YÖRTÜRK Foundation, Ankara.

Catão, L. A. and G. M. Milesi-Ferretti (2014), "External liabilities and crises”, Journal of International Economics, Vol. 94, No. 1, pp. 18-32.

CBRT (2016), Inflation Report 2016-I, Central Bank of the Republic of Turkey.

Ceritoğlu E., B. Gürcihan Yüncüler, H. Torun, S. Tümen (2015), "The Impact of Syrian Refugees on Natives' Labor Market Outcomes in Turkey: Evidence from a Quasi-Experimental Design”, IZA Working Paper No. 9348.

De Backer, K., I. Desnoyers-James and L. Mossiegt (2015), "Manufacturing or services - That is (not) the question?”, OECD Science, Technology and Industry Policy Papers, No. 19, OECD Publishing, Paris.

Del Caprio, X. and M. Wagner (2015), "The impact of Syrian refugees on the Turkish labour market" Policy Research Working Paper (7402), World Bank, Washington.

Devlette (2015), “65 aylığı nedir, kimler alabilir?" (65 year old benefits, entitlement conditions) http://www.devlette.com/65-yas-ayligi-nedir-kimler-alabilir-alma-sartlari-nelerdir/

Dorrucci, E. (2015), "GDP per capita in advanced countries over the 20th century", Presentation to the Conference "Balanced and Sustainable Growth - Operationalising the G20 Framework", European Central Bank, August.

EBRD (2016), European Bank for Reconstruction and Development Transition Report, London.

Égert, B. and A. De Serres (2016), "Regulation, institutions and aggregate investment: New evidence from OECD countries", OECD Economics Department Working Papers (forthcoming).

Ekşi, O. and N. Ekşi (2016), "Life satisfaction and keeping up with other countries", CBRT Working Papers, No. 16/06.

Environmental Performance Index (2016), http://epi.yale.edu/

Erdoğan, M. and C. Ünver (2015), “Türk İş Dünyasının Suriyeli Göçmenler Konusundaki Görüş, Beklenti ve Önerileri (Turkish business sector assessment, expectations and proposals concerning Syrian refugees)", Türkiye İşveren Sendikaları Konfederasyonu, Ankara.

European Union (2015a), "Macroeconomic Imbalance Procedure Website", http://ec.europa.eu/economy_finance/economic_governance/macroeconomic_imbalance_procedure/ mip_reports/index_en.htm

European Union (2015b), Urban Air Pollution: What Are The Main Sources Across the World?, Joint Research Center, https://ec.europa.eu/jrc/en/news/what-are-main-sources-urban-air-pollution.

Furceri, D., S. Guichard and E. Rusticelli (2011), "Episodes of large capital inflows and the likelihood of banking and currency crises and sudden stops", OECD Economics Department Working Papers, No. 865, OECD Publishing, Paris. 
Gereffi, G., and X. Luo (2015), "Risks and opportunities of participation in global value chains", Journal of Banking and Financial Economics, Vol. 2, No. 4, pp. 51-63.

Global Property Guide (2016), Gross Rental Yields - Turkey Compared to Continent, web site content, source: http://www.globalpropertyguide.com/Europe/Turkey/rent-yields.

Hermansen, M. and O. Röhn (2015), "Economic resilience: The usefulness of early warning indicators in OECD countries", OECD Economics Department Working Papers, No. 1250, OECD Publishing.

Hisarcıklığlu, R. (2016), "İflas erteleme için yeni kriterler gelecek” (New criteria necessary for bankruptcy applications), Dünya, 12 April.

Hülagü, T., E. Kızılkaya, A. G. Özbekler and P. Tunar (2016), “A hedonic house price index for Turkey”, Central Bank of the Republic of Turkey Working Papers, No. 16/03.

IMF (2016), Turkey Article IV Consultation: Staff Report and Selected Issues, Washington D.C.

Istanbul Policy Center (2015), Low Carbon Development Pathways and Priorities for Turkey, Sabanc1 University, Istanbul.

Kroll C. (2015), Sustainable Development Goals: Are the Rich Countries Ready? , Sustainable Development Solutions Network, Bertelsmann Stiftung, Washington D.C.

Johansson, A. et al. (2008), “Taxation and economic growth", OECD Economics Department Working Papers, No. 620, OECD Publishing, Paris.

Kal, H., F. Arslaner and N. Arslaner (2015), "Sources of asymmetry and non-linearity in pass-through of exchange rate and import price to consumer price inflation for the Turkish economy during inflation targeting regime", Central Bank of the Republic of Turkey Working Papers, No. 15/30.

Kara, H. et al. (2005), "Exchange rate pass-through in Turkey: Has it changed and to what extent?", Central Bank of the Republic of Turkey Working Papers, No. 05/04.

Kara, H., H. Küçük, T. Tiryaki and C. Yüksel (2014), "In search of a reasonable credit growth rate for Turkey", Central Bank Review, Vol. 14.

Keeley, B. (2015), Income Inequality: The Gap between Rich and Poor, OECD Insights, OECD Publishing, Paris.

Kowalski, P. et al. (2015), "Participation of developing countries in global value chains: Implications for trade and trade-related policies", OECD Trade Policy Papers, No. 179, OECD Publishing.

Kozluk, T. and C. Timiliotis (2016), "Do environmental policies affect global value chains? A new perspective on the pollution haven hypothesis", OECD Economics Department Working Papers, No. 1282, OECD Publishing, Paris.

Mackie, A., I. Hascic and M. Cardenas Rodriguez (2016), "Population exposure to fine particles: methodology and results for OECD and G 20 countries", OECD Green Growth Papers (forthcoming)

Ocean Health Index (2016), http://data.oceanhealthindex.org/scores/76 
OECD (2010), OECD Economic Surveys; Turkey 2010, OECD Publishing, Paris, www.oecd.org/eco/surveys/economic-survey-turkey.htm

OECD (2012), OECD Economic Surveys; Turkey 2012, OECD Publishing, Paris, www.oecd.org/eco/surveys/economic-survey-turkey.htm

OECD (2013a), Supporting Investment in Knowledge Capital, Growth and Innovation, OECD Publishing, Paris.

OECD (2013b), OECD Compendium of Agri-environmental Indicators, OECD Publishing, Paris.

OECD (2013c), Climate Change Impacts on Water Systems, Online Country Profiles: Turkey. http://www.oecd.org/env/resources/turkey.pdf

OECD (2013d), Pursuing Strong, Sustainable and Balanced Growth: G20 Structural Reform Commitments (Jointly with the World Bank), Paris.

OECD (2014a), Economic Survey of Turkey, OECD Publishing, Paris.

OECD (2014b), The Cost of Air Pollution, OECD Publishing, Paris.

OECD (2014c), OECD Reviews of Health Care Quality: Turkey, OECD Publishing, Paris.

OECD (2015a), How's Life? 2015: Measuring Well-Being, OECD Publishing, Paris.

OECD (2015b), Education at a Glance 2015: OECD Indicators, OECD Publishing, Paris.

OECD (2015c), OECD FDI Regulatory Restrictiveness Index, www.oecd.org/investment/fdiindex.htm

OECD (2015d), Taxation of SMEs in OECD and G20 Countries, OECD Publishing, Paris.

OECD (2015e), OECD Companion to the Inventory of Support Measures for Fossil Fuels 2015, OECD Publishing, Paris.

OECD (2015f), Policies to Manage Agricultural Groundwater Use, Online Country Profiles: Turkey, http://www.oecd.org/tad/sustainable-agriculture/groundwater-country-note-TUR-2015\%20final.pdf

OECD (2015g), Science, Technology and Industry Scoreboard, OECD Publishing, Paris.

OECD (2015h), Economic Policy Reforms: Going for Growth, OECD Publishing, Paris.

OECD (2015i), Climate Mitigation Policies: Turkey, in OECD: Compare Your Country, http://www.compareyourcountry.org/climate-policies

OECD (2015k), Employment Outlook, OECD Publishing, Paris.

OECD (20151), In It Together: Why Less Inequality Benefits All, OECD Publishing, Paris.

OECD (2016a), Zero Licencing Initiative, OECD Observatory of Public Sector Innovation website: https://www.oecd.org/governance/observatory-public-sectorinnovation/innovations/page/zerolicensinginitiative.htm 
OECD (2016b), Innovation, Agricultural Productivity and Sustainability in Turkey, (forthcoming), OECD Publishing, Paris.

Özüner (2016), “Eules Hermes Genel Müdürü Özüner: Bu Y11 15 Bin Şirket İflas Edecek” (15 000 bankruptcies expected this year), Dünya, 19 April.

Ziemann and Guérard (2016), "Reaping the benefits of global value chains", OECD Economics Department Working Papers, No. XXXX, OECD Publishing, Paris. 


\section{APPENDIX 1 \\ THE EFFICIENCY OF LABOUR ALLOCATION IN LABOUR-INTENSIVE AND NON- LABOUR INTENSIVE SECTORS}

Given the tendency for highly productive firms to coexist with low productivity firms within narrowly-defined sectors, resource misallocation is increasingly being advanced as a potential explanation for why some countries are more productive than others (Bartelsman et al., 2013; Hsieh and Klenow, 2009). A key observation is that in well-functioning economies, a firm's relative position in the productivity and size distributions is positively correlated, which means that on average relatively more productive firms should command a relatively larger share of industry inputs (Olley and Pakes, 1996). Using this metric, Andrews and Cingano (2014) show that differences in the efficiency of labour allocation across OECD countries are significant and strongly correlated with differences in market regulations. A key result is that in countries with rigid job protection legislation, allocative efficiency tends to be disproportionately lower in sectors more exposed to such policy distortions (i.e. sectors with high labour intensity or job layoff rates) than in other sectors. This note shows that a similar pattern holds in Turkey, suggesting that rigid labour market regulations are undermining productivity performance. Moreover, the aggregate productivity gains from labour market reforms that improve resource allocation in the labour intensive sectors in Turkey are potentially sizeable.

\section{Measuring allocative efficiency}

According to Olley-Pakes (1996), at any point in time, differences in aggregate productivity will reflect: $i$ ) the productivity distribution of firms (i.e. the fraction of 'better' relative to 'worse' firms); and $i i$ ) the extent to which, all else equal, it is the more productive firms that command a larger share of industry value added (i.e. allocative efficiency), which will be the outcome of the shift in resources across firms in previous periods. More formally, an index of productivity of industry $j$, defined as the weighted average of firm-level productivity $\left(P_{j}=\sum_{i \in j} \theta_{i} P_{i}\right)$, can be written as:

$$
\sum_{i \in j} \theta_{i} P_{i}=\bar{P}_{j}+\sum_{i \in j}\left(\theta_{i}-\overline{\theta_{j}}\right)\left(P_{i}-\overline{P_{j}}\right)
$$

where $\bar{P}_{j}=1 / N_{j} \sum_{i \in j} P_{i}$ is the unweighted firm productivity mean (based upon sales per worker), $\theta_{i}$ is a measure of the relative size of each firm (e.g. the firm employment share) and $\bar{\theta}_{j}=1 / N_{j}$ is the average share at the industry level. Hence, aggregate productivity $\left(P_{j}\right)$ can be decomposed into a moment of the firm productivity distribution (the unweighted mean) and a joint moment with the firm size distribution reflecting the extent to which firms with higher efficiency also have a larger relative size: the "Olley-Pakes covariance" term or static allocative efficiency (henceforth AE). By convention, $\mathrm{P}$ denotes logproductivity.

\section{Policy distortions reduce allocative efficiency}

The scope for increasing aggregate productivity by reducing misallocation is potentially large. For instance, cross-country estimates of AE suggest that more productive firms are likely to account for a much larger share of employment in the United States than in the European Union (Figure 1; Andrews and Cingano, 2014). Relative to a random allocation of labour across firms, this actual allocation of labour 
boosts manufacturing sector labour productivity by almost $60 \%$ in the United States, but only by $30 \%$ across the European Union on average. Digging deeper, significant differences also emerge within Europe, ranging from relatively efficient labour allocation in some Nordic economies to widespread misallocation in southern Europe. ${ }^{2}$ Countries which perform poorly on this metric also exhibit high rates of skill mismatch, which in turn reflects low labour mobility in these countries more generally (Adalet McGowan and Andrews, 2015a, b).

Figure A.1. Labour reallocation in OECD countries

Static allocative efficiency - contribution of the allocation of employment across firms to the level of labour productivity (\%)

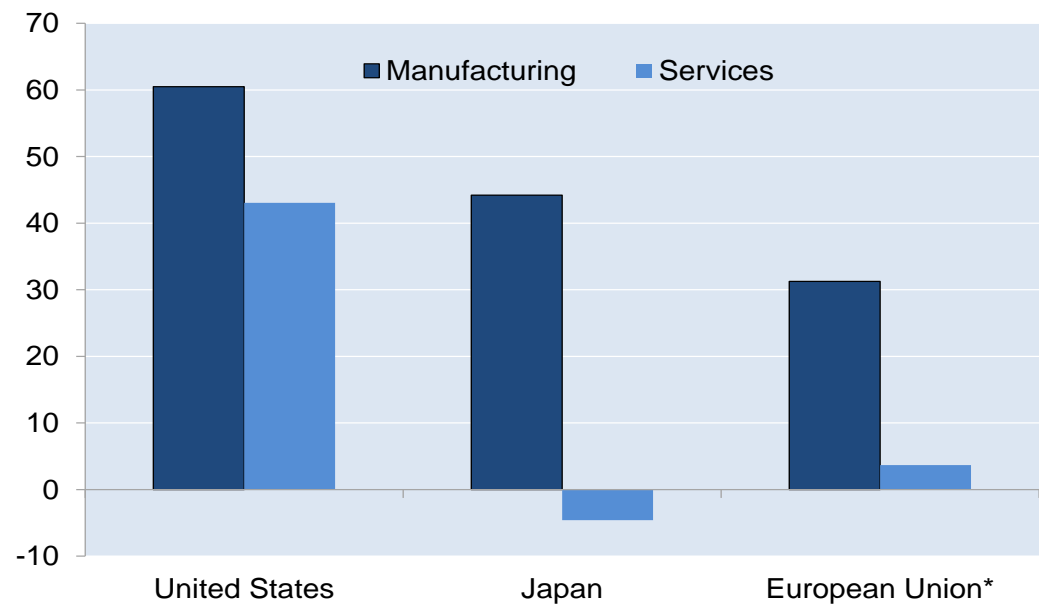

Notes: The estimates in Panel A show the extent to which firms with higher than average labour productivity have larger employment shares. For example, productivity in the manufacturing sector in the US is around $60 \%$ higher due to the actual allocation of employment, compared to a baseline in which labour is allocated randomly across firms (index=0).

Source: Andrews and Cingano (2014).

Differences in resource allocation are linked to many factors, among which differences in regulations affecting product and labour markets. At least one-half of the US-EU gap in AE is accounted for by policy differences according to some estimates (Andrews and Cingano, 2014). In the spirit of Rajan and Zingales (1998), the analysis shows that in countries with stringent employment protection legislation (EPL), AE tends to be much lower in industries more sensitive to distortions affecting labour reallocation - i.e. those with naturally higher labour intensity or job layoff rates. Similarly, in countries where policy-induced entry and exit barriers in product markets are stringent, AE tends to be much lower in sectors with naturally higher firm entry and exit rates than in other countries.

To investigate these ideas further, Table 1 shows average differences in AE across labour intensive and non-labour intensive manufacturing sectors for Turkey and three comparison economies: the European Union, the United States and United Kingdom. Two key ideas emerge. First, differences in AE between labour intensive and non-labour intensive sectors are much smaller in the United States and United Kingdom - two countries with very low job protection - than in the European Union, where labour regulations are more stringent. Second, the gap in AE between the two sector groupings is even larger in Turkey - a country where labour market reform is an even more pressing policy priority. Indeed, what is

2 More generally, these findings are consistent with recent research highlighting significant cross-country differences in: i) the size of firms at the national productivity frontier (Andrews, Criscuolo and Gal, 2015); ii) the ability for innovative firms to attract resources (Andrews, Criscuolo and Menon, 2014); and iii) the size and post-entry growth patterns of firms (Criscuolo, Gal and Menon, 2015). 
particularly striking is the fact that the AE index in labour intensive industries - where labour regulations should be most binding - is actually negative. This suggests that the allocation of labour across firms in these sectors in Turkey is worse than a random draw - i.e. more productive firms actually command fewer resources than less productive firms. This provides a "smoking gun" about the productivity consequences of poorly designed labour regulations in Turkey.

Table A.1. Allocative efficiency in manufacturing sectors

\begin{tabular}{lc|ccc|} 
& Turkey & EU-14 & United States & United Kingdom \\
\hline (1) Labour intensive & -0.12 & 0.06 & 0.27 & 0.25 \\
(2) Non-labour intensive & 0.32 & 0.19 & 0.46 & 0.21 \\
(3) Ratio of (1) to (2) & -- & 0.3 & 0.6 & 1.2 \\
\hline
\end{tabular}

Note: Estimates for Turkey on the basis of CBRT data, according to the methodology in Andrews and Cingano (2014). Estimates for Europe-14, the United States and United Kingdom are sourced from Andrews and Cingano (2014). Europe-14 includes: Austria, Belgium, Czech Republic, France, Greece, Germany, Hungary, Italy, Netherlands, Portugal, Poland, Spain, Slovak Republic and Switzerland. The result is obtained by aggregating the respective allocative efficiency indicators by each country's share in manufacturing sector employment.

\section{How much scope is there for labour market reform to boost labour productivity?}

These estimates raise the question of how much Turkey stands to gain from reforms to job protection legislation. To provide a ballpark estimate, Table 2 simulates how much $\mathrm{AE}$ in the fully formal manufacturing sector would rise if Turkey could reduce the gap in AE between labour intensive and nonlabour intensive sectors to that observed in economies with less rigid labour market regulations: the European Union, United States and the United Kingdom. A key assumption is that reducing the stringency of job protection legislation only affects the efficiency of labour allocation in labour intensive sectors as these are the sectors that are most exposed to the reform. However, the gains could be much larger if the reform engendered an improvement in allocative efficiency in non-labour intensive sectors or a productivity-enhancing reallocation of across sectors.

Table A.2: Simulated labour productivity gains from reducing the allocative efficiency gap between labour intensive and non-labour intensive sectors

\begin{tabular}{|c|c|c|c|c|}
\hline & \multicolumn{3}{|c|}{$\begin{array}{l}\text { Implied gain from Turkey reducing its gap in } \\
\text { allocative efficiency (AE) between (1) and (2) to } \\
\text { that observed in: }\end{array}$} & \multirow{2}{*}{$\begin{array}{l}\text { Memo: share of } \\
\text { manufacturing sector } \\
\text { employment in Turkey }\end{array}$} \\
\hline & $\mathrm{EU}-14^{*}$ & $\begin{array}{l}\text { United } \\
\text { States }\end{array}$ & $\begin{array}{l}\text { United } \\
\text { Kingdom }\end{array}$ & \\
\hline (1) Labour intensive & 0.09 & 0.19 & 0.38 & 0.38 \\
\hline (2) Non-labour intensive & 0.32 & 0.32 & 0.32 & 0.63 \\
\hline \multicolumn{4}{|c|}{ Aggregate manufacturing sector } & \\
\hline (3) Counterfactual AE & 0.23 & 0.27 & 0.34 & \\
\hline (4) Actual AE & 0.15 & 0.15 & 0.15 & \\
\hline$(5=3-4)$ Implied gain to $A E$ & 0.08 & 0.12 & 0.19 & \\
\hline
\end{tabular}

Note: See Table 1.

Under the US benchmark where AE in fully formal labour intensive sectors in Turkey is assumed to rise to $60 \%$ of the level in non-labour intensive ones, $\mathrm{AE}$ in the labour intensive sectors would increase to $19 \log$ points, from $-12 \log$ points (a gain of $31 \log$ points). Given that labour intensive sectors account for 
$38 \%$ of total fully formal manufacturing employment, this implies that AE in aggregate fully formal manufacturing would increase to $27 \log$ points - representing a gain of around $12 \log$ points to aggregate manufacturing labour productivity (i.e. $31 * 0.38$ ). The implied gains are even larger when the United Kingdom is a benchmark - i.e. aggregate manufacturing labour productivity could rise by $19 \%$ under this scenario - reflecting the fact that $\mathrm{AE}$ is somewhat higher in labour intensive relative than non-labour intensive sectors in the United Kingdom. Alternatively, taking an average of the United States and United Kingdom implies gains of around 15\% to manufacturing labour productivity if Turkey's labour market regulations where to converge to best practice in the OECD.

Finally, the gains from reducing the stringency of product market regulations (PMR) are also potentially significant in Turkey. As noted above, PMR - especially those imposing administrative barriers on start-up firms - are more likely to bind in sectors that display naturally higher rates of firm turnover (firm entry + firm exit), than in other sectors. As discussed in Andrews and Cingano (2014), in the EU where PMR tends to be more restrictive, AE is significantly lower in sectors with high firm turnover (i.e. sectors in top quartile of the US firm turnover distribution) compared with sectors with lower firm turnover. By contrast, in the United States and United Kingdom where PMR are less restrictive, there is little difference in AE estimates across these sector groupings. ${ }^{3}$ For Turkey, the AE index is much lower in sectors more exposed to PMR ( 0.02 on average across sectors with above-average firm turnover), while it is much higher in sectors less exposed to PMR (i.e. 0.20 in sectors below-average firm turnover). These estimates suggest that there are also potentially gains from PMR reform in Turkey.

3 In this exercise, firm turnover rates are based on US data. 